\title{
Experiences of Select Women Doctoral Students: A Feminist Standpoint Theory Perspective
}

\author{
Valerie T Byers ${ }^{1}$, Rachel N Smith ${ }^{1}$, Kay E Angrove ${ }^{1}$, Leah McAlister-Shields ${ }^{1}$ \& Anthony $\mathbf{J}$ \\ Onwuegbuzie ${ }^{1, *}$ \\ ${ }^{1}$ Department of Educational Leadership, Box 2119, Sam Houston State University, Huntsville, \\ Texas 77341-2119, USA \\ *Corresponding author: Department of Educational Leadership, Box 2119, Sam Houston \\ State University, Huntsville, Texas 77341-2119, USA. E-mail: tonyonwuegbuzie@aol.com
}

Received: January 21, 2015 Accepted: February 12, 2015 Published: March 31, 2015

doi:10.5296/ije.v7i1.6982ＵRL: http://dx.doi.org/10.5296/ije.v7i1.6982

\begin{abstract}
This mixed research study of the experiences of select women doctoral students was guided by feminist standpoint theory. Specifically, the standpoints of 8 women doctoral students were examined, with 2 men doctoral students included in the study for comparison purposes. This study involved the inclusion of participant-researchers in order to obtain emtic (i.e., both emic and etic) viewpoints. A fully mixed concurrent dominant status design was utilized. Findings revealed 4 themes which indicated that although the women doctoral students received support and encouragement to tackle the multitude of challenges that they faced, particularly in terms of balancing one's academic identity with other identities, they still felt a strong sense of remorse and guilt towards the sacrifices that they had to make in order to succeed within their doctoral programs - in contrast to the men doctoral students who, although they felt some guilt, faced their challenges more by focusing on achieving their goals and the implied results (i.e., career success) of that achievement. These findings have important implications - at least for these students — with regard to the structuring of doctoral programs.
\end{abstract}

Keywords: feminist standpoint theory; women doctoral students; doctoral programs; lived experiences; mixed methods research; mixed research; fully mixed concurrent dominant status design 


\section{Feminist Standpoint Theory}

Feminist Standpoint Theory (FST) involves investigating how power and knowledge are connected to experiences, and making that power visible to inform situated experiences of women (Anderson, 2011; Ramazanoglu \& Holland, 2002). Although feminist scholars have disagreed on some of the tenets of FST (e.g., Haraway, 2004; Harding, 2004b; Hartsock, 2004), these scholars have the same goal of attempting to add to the knowledge of women's lived experiences (Olesen, 2005). Broadly speaking, FST promotes the exploration of women's standpoints (perspectives) and lived experiences in their own voices (Lather, 1992; Olesen, 2005; Ramazanoglu \& Holland, 2002). Standpoints emerge out of the unique societal context of their relationships with power (Crain Bertsch, 2012; Olesen, 2005; Ramazanoglu $\&$ Holland, 2002). A vital tenet of FST is that women must tell their stories while "attentive to the perspective of the dominant class (e.g., White, male, wealth) as well as their own" (Nielsen, 1990, p. 10). As stated by Crasnow (2009),

If the informants are unable to give testimony because they do not have the words to do so (hermeneutical injustice), or if they are unwilling because they do not trust the researcher, access to evidence is limited or even impossible. As a methodology, standpoint theory provides both a means of uncovering the power relations that create such silence and of creating the trust necessary to access informants' evidence. (p. 191)

Ramazanoglu and Holland (2002) summarized five characteristics of FST that have emerged as commonly held tenets: (a) FST explores connections between knowledge and power; (b) each woman researcher and woman participant is socially located in unique and specific ways of thinking and knowing; (c) FST is grounded in women voicing their experiences; (d) FST researchers must honor the diverse experiences of woman, and the power relationships among women (i.e., specifically, differences in social situations, relationships, and power among women participants or researchers in contrast to external power relationships); and (e) that feminist standpoint knowledge, by the fact that it is individually situated and experienced, is only partial knowledge and, therefore, makes no claim to a generalized knowledge of women. Alternatively stated, FST is grounded in locally situated knowledge that cannot be generalized (Ramazanoglu \& Holland, 2002).

Olesen (2005) cautioned that FST scholars are diverse in their approaches to qualitative research and recommended an informed understanding of the debate and diversity within this standpoint. Specifically, according to Olesen (2005),

Research and writing by sociologist Dorothy Smith, sociologist Patricia Hill Collins, political scientist Nancy Hartsock, and philosopher Sandra Harding dissolved the concept of essentialized, universalized woman, which was to be replaced by the ideas of a situated woman with experiences and knowledge specific to her place in the material division of labor and racial stratification systems. (p. 243)

Moreover, FST focuses on the idea that women's standpoints always are evolving based on new unique lived experiences of women within a situated understanding of distinct but 
different external factors (e.g., institutional, political, and historical power structures). Additionally, within the gender group defined as women, there are diverse subgroups with differentiated experiences that are situated in different social constructs. Thus, the nature of unique lived experiences among women creates a "concrete multiplicity" of perspectives (Harding, 1993, p. 56). Furthermore, any standpoint theory, which variably includes men and women of color, of different sexual orientations, of various exceptionalities, and so forth "claims that all knowledge attempts are socially situated" (Olesen, 2005, p. 243).

Informed by FST, Mansfield, Welton, Lee, and Young (2010) sought to understand the challenges and opportunities of women doctoral students in educational leadership departments. A qualitative questionnaire and a collaborative focus group consisting of 12 women representing a variety of demographic characteristics (i.e., one Black, two Asian, two Latinas, one multiracial, and six White) were surveyed to explore participants' experiences and perceptions with the intent of revealing strategies to support the success of women doctoral students. Limitations within the organizational culture (i.e., confusion about access to professional networks within the academic community); personal and family sacrifices (i.e., the stress of work and school time constraints exacerbated time for familial life); identity issues (i.e., race, ethnicity, age, social class, language, and immigrant status added complexity to the doctoral experience); self-doubts, and mentoring experiences emerged as themes from the participants' perceptions (Mansfield et al., 2010). These findings have important implications for designing doctoral programs that explicitly identify and address disparities in access to professional networks for women within the academic organization. Attention to the unique personal sacrifices and the associated perceived reduction in ability to parent that was experienced among women pursuing a doctorate should serve to improve transparency of women's issues and, thus, help to address feelings of insecurity, identity issues, and professional equality.

Ülkü-Steiner, Kurtz-Costes and Kinlaw (2000) conducted a study of two cohorts wherein men and women doctoral students in programs containing gender-balanced faculty members and in programs containing male-dominated faculty members were compared with respect to student experiences of social support, academic self-concept, departmental sensitivity to family issues, stress, mentor support, and career commitment. Faculty and student gender composition were examined as criteria for the department selection process. Departments containing gender-balanced faculty members and containing male-dominated faculty members were selected only if the student populations in each group were gender-balanced in order to control for gender effects among students. Men and women doctoral students participated from each of 14 different disciplines, comprising 341 second- through sixth-year graduate students; 193 were women, and 148 were men; 122 (90 women, 32 men) were enrolled in faculty gender-balanced programs, and 219 students (103 women, 116 men) were enrolled in faculty male-dominated programs. Survey data were collected on two occasions, 2 years apart. In Study 1, conducted during the 1996-1997 academic school year, women in the male-dominated doctoral programs reported less sensitivity with regard to family issues, lower academic self-concepts, and lower career commitment than did the other three student groups (i.e., men in male-dominated doctoral programs; women in gender-balanced doctoral 
programs; and men in gender-balanced doctoral programs). There were 50 students who reported supporting one or more children in their homes, and they experienced less peer support compared with their non-parenting peers (Ülkü-Steiner et al., 2000).

Participants for Study 2 also were doctoral students from the same 14 departments as were the Study 1 participants. Study 2 survey data were collected during the 1998-1999 academic year. Students in the male-dominated programs reported lower self-concept than did students in gender-balanced programs. Compared with other students, women in male-dominated programs reported more support from partners, less sensitivity toward family issues in their respective departments, and lower career commitment than did the other students. Forty-six students reported having one or more children. Of these students, 14 were women in gender-balanced programs, seven were women in male-dominated programs, eight were men in gender-balanced programs, and 17 were men in male-dominated programs. When students with $(n=46)$ and without $(n=320)$ children were compared, parenthood negatively correlated with peer support - that is, students with children reported less peer support than did their non-parenting peers. No other variables were statistically significantly different (Ülkü-Steiner et al., 2000).

Variables of mentor support, peer support, partner support, academic self-concept, and stress were significantly correlated to career commitment for all women in Study 2. Ülkü-Steiner et al. (2000) concluded that "The relationship between student-gender and faculty-gender ratios was the defining feature of student experiences, rather than student gender alone" (p. 304). Furthermore, Ülkü-Steiner et al. (2000) noted that this finding was critical in revealing that women in male-dominated academic departments were significantly more negatively impacted in their commitment to careers than were men in the same program.

In the case of our current study, the women doctoral students were enrolled in an educational leadership department dominated by women faculty and women leadership. Our FST process began with an inquiry situated in select women doctoral students' everyday lives and, participating in the role of participant-researchers, the women participant-researchers were free to construct and to explore their own questions (Harding, 2004a). Two male members of the program who were enrolled in the same cohort as were these women also were included in the study, providing a valuable comparison group. Including a comparison group in FST research studies can prevent researchers from forming an illusory correlation (i.e., tendency to identify a relationship among events, people, and so forth, when no such relationship actually exists; Onwuegbuzie \& Leech, 2007), confirmatory bias (i.e., tendency for interpretations and conclusions based on new data to be overly consistent with a priori assumptions and hunches; Greenwald, Pratkanis, Leippe, \& Baumgardner, 1986), and causal error (i.e., obtaining causal explanations and attributions for observed behaviors and attitudes without attempting to verify such interpretations; Onwuegbuzie \& Leech, 2007). Using a FST lens supported the exploration of women's voices and their constructions of the problems and opportunities that they experience (Harding, 2004a). The research process was collaborative, with participants emerging as partners whose voices were immersed in multiple stages of the research process - such as in data collection, analysis and interpretation - in keeping with the tenets of FST (Lather, 1992). Women doctoral students reported experiences in order to 
analyze how social and political perspectives look from the women's standpoints of their daily lives. Women's standpoints are important sources of situated knowledge that can inform new knowledge and practice by illuminating their unique experiences (Harding, 2004a).

\section{Mixed Research Question}

The following mixed research question was addressed: In what ways, if any, are select women doctoral students able to navigate successfully their doctoral degree programs?

\section{Theoretical Framework}

The theoretical lens used for our study was FST (Ramazanoglu \& Holland, 2002; Swigonski, 1993, 1994). As noted previously, FST involves researching the everyday lives of women in order to yield a more meaningful account of women's social worlds (Olesen, 2005). As part of this stance, each participant assumed the role of participant and researcher, yielding an individual voice and a cohesive group of participant-researchers. This created an environment of trust necessary in FST for revealing authentic power relationships (Crasnow, 2009). As a result of using FST, collaboration was promoted among the women participant-researchers at every phase of the study (Swigonski, 1993).

\section{Methodological Framework}

The methodological framework for this study was a 13-step process (Collins, Onwuegbuzie, \& Sutton, 2006) that occurred in the following three stages: (a) the Conceptualization Stage (i.e., determine the mixed goal, objective, rationale, purpose, and research question[s]); (b) the Planning Stage (i.e., select the mixed sampling and research design); and (c) the Implementation Phase (i.e., collect and analyze quantitative and/or qualitative data, validate/legitimate and interpret the mixed research findings, write the mixed research report, and reformulate the mixed research question[s]). The methodological steps within each phase are interactive and recursive (Collins et al., 2006).

\section{Method}

\section{Participants and Setting}

Participants were eight women doctoral students and two men doctoral students who were enrolled in the educational leadership program at a Tier-II public university in the southeast United States (U.S. News and World Report, 2012). We selected our informants purposively due to their program participation, thereby yielding a criterion sampling scheme (Onwuegbuzie \& Collins, 2007). Because qualitative research normally focuses on small samples of participants for in-depth study of their particular situation, we deemed this purposeful sample of 10 students to be adequate for the current study (Miles \& Huberman, 1994). Further, as concluded by Johnson and Christensen (2010), "when greater resources are available, collective case studies of around 10 cases are common" (p. 397). Also, as demonstrated by Guest, Bunce, and Johnson (2006), six interviews might be "sufficient to 
enable development of meaningful themes and useful interpretations" (p. 78). Thus, we judged our sample size of 10 interviewees as being adequate for obtaining data saturation.

The majority of participants was White (70\%) and ranged in age from 30 to 59 years $(M=39.9$, $S D=10.75)$. In terms of gender, the majority of participants was women $(n=8)$, with the two men serving as the comparison group. All participants were pursuing an Ed.D. in Educational Leadership. With respect to race and ethnicity, seven out of 10 participants were White, two were African American, and one participant was Asian. For the purposes of this study, we will refer to the participants by their pseudonyms: Agnes, Beatrice, Calvin, Constance, Dixie, Delores, Hazel, Matilda, Sophia, and Thaddeus. Table 1 displays the participants' demographic information in more detail.

Table 1. Demographic Information of Participants

\begin{tabular}{|c|c|c|c|c|}
\hline Alias & Gender & Race & Age & Profession \\
\hline Agnes & Female & White & 57 & $\begin{array}{l}\text { Director of First-Year } \\
\text { Experience }\end{array}$ \\
\hline Beatrice & Female & White & 30 & Adjunct Professor \\
\hline Calvin & Male & White & 30 & Assistant Athletic Director \\
\hline Constance & Female & White & 31 & $\begin{array}{l}\text { Director of Corporate \& } \\
\text { Foundation Relations }\end{array}$ \\
\hline Dixie & Female & Black & 59 & Library Director \\
\hline Delores & Female & White & 45 & $\begin{array}{l}\text { Manager of Professional } \\
\text { Development Programs }\end{array}$ \\
\hline Hazel & Female & Asian & 37 & $\begin{array}{l}\text { Doctoral Research } \\
\text { Assistant }\end{array}$ \\
\hline Matilda & Female & Black & 33 & $\begin{array}{l}\text { Academic Program } \\
\text { Manager }\end{array}$ \\
\hline Sophia & Female & White & 36 & Professor \\
\hline Thaddeus & Male & White & 42 & $\begin{array}{l}\text { Associate Director of } \\
\text { Recreational Sports }\end{array}$ \\
\hline
\end{tabular}

In terms of the program itself, the 60-hour doctoral program in educational leadership followed a cohort model in which the participants began the program as a group and progressed through coursework and each stage of the program together. With exception of one participant, namely Delores, the remaining participants matriculated into the program in January 2011. Throughout the duration of the program, the students were enrolled in a minimum of two classes each spring, summer, and fall semester. The initial data (i.e., interviews) were collected at the beginning of the fourth semester in the program (i.e., 
February 2012). The second data (i.e., follow-up responses) were collected at the end of the sixth semester in the program (i.e., December 2012). After the participants completed seven consecutive semesters of both required and elective coursework (i.e., 47 credit hours), the participants were required successfully to complete a written comprehensive examination in which they demonstrated competencies in research tools and the ability to synthesize course information. During the eighth semester of the program (i.e., June 2013), participants began the last requirement of the program - a major individual independent research study resulting in the presentation and defense of a dissertation. During the dissertation process, each participant was required to present a proposal to his or her committee, to gain approval by the committee and the university's Institutional Review Board, to collect data, to analyze data, to write up conclusions and implications for the results, and to present a final defense to the committee. Calvin was the first participant in the cohort to complete the program and graduate in May 2014. Delores belonged to a previous cohort, and she completed the program in August 2013. To date, only one other participant, namely, Matilda, has completed the first stage of the dissertation process (i.e., the proposal defense). Table 2 summarizes the progress of each participant with respect to the final stage of the program.

Table 2. Progression of Participants

\begin{tabular}{|c|c|c|c|c|c|c|}
\hline Alias & $\begin{array}{c}\text { Comprehensive } \\
\text { Examination (Date } \\
\text { of Notification of } \\
\text { Successful } \\
\text { Completion) }\end{array}$ & $\begin{array}{l}\text { Topic Secured } \\
\text { for Major } \\
\text { Research } \\
\text { Study } \\
\text { (Yes or No) }\end{array}$ & $\begin{array}{c}\text { Type of } \\
\text { Research Design } \\
\text { (Quantitative, } \\
\text { Qualitative, or } \\
\text { Mixed Methods) }\end{array}$ & $\begin{array}{c}\text { Dissertation } \\
\text { Proposal (Date of } \\
\text { Completion) }\end{array}$ & $\begin{array}{c}\text { Final Dissertation } \\
\text { Defense } \\
\text { (Date of } \\
\text { Completion) }\end{array}$ & $\begin{array}{c}\text { Completion of } \\
\text { Doctoral Program } \\
\text { (Date of } \\
\text { Graduation) }\end{array}$ \\
\hline Agnes & July 2013 & Yes & Quantitative & & & \\
\hline Beatrice & July 2013 & Yes & Qualitative & & & \\
\hline Calvin & July 2013 & Yes & Quantitative & October 2013 & February 2014 & May 2014 \\
\hline Constance & July 2013 & Yes & Quantitative & & & \\
\hline Dixie & July 2013 & Yes & Qualitative & March 2015 & & \\
\hline Delores & October 2011 & Yes & Quantitative & November 2012 & May 2013 & August 2013 \\
\hline Hazel & July 2013 & Yes & Mixed & & & \\
\hline Matilda & July 2013 & Yes & Mixed & July 2014 & & \\
\hline Sophia & July 2013 & Yes & Mixed & & & \\
\hline Thaddeus & & No & & & & \\
\hline
\end{tabular}

\section{Instruments and Procedures}

We engaged each participant-researcher in at least one semi-structured, face-to-face interview to address the research question. By asking pre-formulated, open-ended questions, we hoped to gather rich, long responses as our interviewees told their individual stories (Kvale, 1996). The purpose of conducting face-to-face interviews was to allow us to clarify meanings, to verify interpretations, and to ask relevant follow-up questions while being able to note any 
nonverbal behaviors (Kvale, 1996).

We co-constructed the open-ended interview questions to assess each participant's experiences in the doctoral program. The interview questions included the following: (a) What challenges, if any, have you experienced since beginning your doctoral program?; and (b) What strategies, if any, have you used to address these challenges? These questions represented various types of categories, including basic descriptive, experience/example, and comparison/contrast (Janesick, 2004). Combined with the follow-up questions (e.g., "Are there any particular challenges that you have in terms of mothering while participating in this program?") utilized in the semi-structured format, the interview questions helped to build a rich picture of the participants' experiences.

Because we were the primary research instruments (Poggenpoel \& Myburgh, 2003) and authenticity in formulating qualitative research is essential (Guba \& Lincoln, 1989; Nolan, Hanson, Magnusson, \& Andersson, 2003), all researchers who were involved in interviewing the participants underwent debriefing interviews themselves, conducted by other members of our research team, as conceptualized by Onwuegbuzie, Leech, and Collins (2008). Onwuegbuzie et al. (2008) developed questions for debriefing researchers using Guba and Lincoln's (1989) authenticity criteria that embrace (social) constructionist understanding and assist in increasing legitimation: (a) fairness (i.e., the extent to which the researcher values the process of evaluation), (b) ontological authenticity (i.e., the extent to which the researcher assesses how the participant has become more informed and aware), (c) educative authenticity (i.e., the criteria by which those involved in the interview process have become more understanding of others), (d) catalytic authenticity (i.e., the extent by which actions are facilitated and stimulated by participants), and (e) tactical authenticity (i.e., the extent to which participants are empowered to act on the results and subsequent understanding from a given study). We transcribed all the participant interviews and debriefing interviews, and then subjected these transcriptions to member checking (Lincoln \& Guba, 1985) in order to maximize descriptive validity (Maxwell, 1992). As noted by Manning (1997), "thorough member checking, including respondent review of field notes, working hypotheses, and case study drafts, means that the researcher is accountable to those sharing their words, lives, and experiences" (p. 102). Additionally, according to Onwuegbuzie et al. (2008), debriefing interviews serve to promote reflexivity, to identify biases in interpretation of data, and to obtain rich insights as to ways that the findings impacted the participants, stakeholders (e.g., advisors, mentors, program developers), and the researchers themselves. Finally, follow-up questionnaires were developed based on the participants' previous interview responses and distributed to each participant. By including interviews, debriefing, and follow-up question responses, we were able to obtain a rich understanding of our participants' experiences.

In the quantitative phase, the participant-researchers were administered the Noncognitive Questionnaire (NCQ; Sedlacek, 2004a). The NCQ is a brief questionnaire measuring eight noncognitive variables. It is particularly appropriate for nontraditional students, including students of color. The eight scales of the NCQ are: Self-Concept, Realistic Self-Appraisal, Understanding Racism, Long Range Goals, Leadership, Strong Support Person, Community Involvement, and Nontraditional Knowledge. The supplementing of interview data with 
information from quantitative instruments has been advanced by Frels and Onwuegbuzie (2013) as a means of enhancing interpretations by helping researchers better contextualize qualitative findings. The NCQ was deemed as being ideal for this study of how effective women are in navigating their doctoral degree programs because it assesses attributes that have been found to be more predictive of success among graduate students in general (Sedlacek, 2004b) and women students in particular (Ancis \& Sedlacek, 1997) than are cognitive variables such as standardized test scores. Including scores from the NCQ alongside the narrative (i.e., verbal and nonverbal) data extracted from the interviews, yielded one or more of the following rationales for mixing qualitative and quantitative data identified by Collins et al. (2006): participant enrichment (i.e., optimizing the quality of data yielded by each sample member) and significance enhancement (i.e., enhancing meaning by analyzing thick and rich data).

\section{Research Design}

Using Leech and Onwuegbuzie's (2009) typology, this study was classified as a fully mixed concurrent dominant status design because: (a) qualitative and quantitative approaches were mixed within multiple stages of the research process; (b) qualitative and quantitative data were collected and analyzed simultaneously, and (c) the qualitative component was given the most weight. The design pertinent to the qualitative phases of the investigation (i.e., interviews, debriefing interviews) represented a collective case study (Stake, 2005). A descriptive research design was used for the quantitative phase.

\section{Data Analysis}

We entered the interview transcriptions and responses to follow-up questions as separate cases into qualitative data software programs, namely, QDA Miner Version 4.0.3 (Provalis Research, 2011a) and WordStat Version 6.1.4 (Provalis Research, 2010), to facilitate a constant comparison analysis (Glaser, 1965; Glaser \& Strauss, 1967) and a classical content analysis (Berelson, 1952), respectively. When conducting constant comparison analysis, we hoped to generate a theory or a set of themes (Leech \& Onwuegbuzie, 2008). According to Glaser (1965), constant comparison analysis is conducted to generate theory by using a more systematic and exhaustive process. In conducting a constant comparison analysis, we underwent the three stages outlined by Strauss and Corbin (1998), namely: open coding (i.e., chunking the data into smaller segments, and then attaching a descriptor, or code, for each segment; Strauss \& Corbin, 1998), axial coding (i.e., grouping the codes into similar categories; Strauss \& Corbin, 1998), and selective coding (i.e., integrating and refining the theory; Strauss \& Corbin, 1998). Also, we used classical content analysis (Berelson, 1952) to determine the frequencies of the themes extracted via the constant comparison analysis. Further, using Miles and Huberman's (1994) framework, we conducted a series of cross-case (e.g., causal networks, in which all participants were comparatively analyzed using variables considered to be the most influential [i.e., coping strategies] in explaining the outcome [i.e., challenges]) and within-case (e.g., conceptually ordered displays [i.e., via visual representations, participants were ordered by concepts]) analyses.

As part of the cross-case analysis, we undertook three sets of correspondence analyses. 
Broadly speaking, a correspondence analysis is an exploratory multivariate technique that involves factoring or clustering categorical (i.e., nominal level) variables and displaying them (i.e., mapping them) in a property space that displays their associations in two or more dimensions (Michailidis, 2007). Specifically, we used correspondence analysis to analyze (a) patterns of communication vagueness; (b) relationships among the emergent themes, among study participants in reference to these themes, and between the emergent themes and the study participants; and (c) patterns of nonverbal communication. The QDA Miner 4.0.3 software program (Provalis Research, 2011a) was used to conduct the series of correspondence analyses. This analysis represented what Onwuegbuzie and Combs (2010) called a crossover mixed analysis, which represents the analysis types associated with one tradition (i.e., quantitative analysis: correspondence analysis) being used to analyze data associated with a different tradition (i.e., qualitative data: emergent themes). More specifically, we utilized a qualitative-dominant crossover mixed analysis wherein the qualitative analysis was dominant, while, simultaneously, we considered the inclusion of quantitative analysis to be helpful in providing richer data and interpretations (Onwuegbuzie $\&$ Combs, 2010). Most importantly, conducting a correspondence analysis ensured that we did not engage in what Bazeley (2009) refers to as a superficial reporting of themes in which "qualitative researchers rely on the presentation of key themes supported by quotes from participants' text as the primary form of analysis and reporting of their data" (p. 6).

Further, we analyzed each interview with respect to the nonverbal behaviors exhibited by the participant. Specifically, we analyzed this nonverbal data via Gorden's (1980) four basic nonverbal modes of communication: (a) proxemics, which represents how each participant used interpersonal space to communicate her/his ideas; (b) chronemic, which represents how silence and speech were utilized by each participant; (c) kinesic, which refers to body movement and postures exhibited by each participant; and (d) paralinguistic, which includes variations in volume, pitch, and quality of voice of each participant. Also, we used Ekman's (1999) framework for observing innate facial expressions. Ekman (1999, p. 56) conceptualized the following 15 emotions that he contended are all distinguishable from each other: amusement, anger, contempt, contentment, disgust, embarrassment, excitement, fear, guilt, pride in achievement, relief, sadness/distress, satisfaction, sensory pleasure, and shame. According to Ekman (1999), these 15 emotions are unique from each other in the following ways: (a) distinctive universal signals; (b) distinctive physiology; (c) automatic appraisal, turned to; (d) distinctive universals in antecedent events; (e) distinctive appearance developmentally; (f) presence in other primates; (g) quick onset; (h) brief duration; (i) unbidden occurrence; (j) distinctive thoughts, memories, images; and (k) distinctive subjective experience. Examining the nonverbal cues of all the participants provided a more in-depth understanding of the participants' experiences.

Onwuegbuzie and Teddlie (2003) conceptualized the following seven stages of the mixed analysis process: (a) data reduction, (b) data display, (c) data transformation, (d) data correlation, (e) data consolidation, (f) data comparison, and (g) data integration. In the present study, we used five of Onwuegbuzie and Teddlie's (2003) seven stages, namely: data reduction, data display, data transformation, data correlation, and data integration. 


\section{Nl Macrothink}

International Journal of Education

ISSN 1948-5476

2015, Vol. 7, No. 1

Specifically, qualitative data were reduced to codes and themes (i.e., data reduction), qualitative and quantitative data were displayed in tables and figures (i.e., data display), quantitative data (e.g., NCQ scores) were correlated with qualitative data (i.e., themes) (i.e., data correlation), and qualitative and quantitative findings from the data were integrated (i.e., data integration). Finally, Onwuegbuzie and Combs (2010) conceptualized that, optimally, mixed researchers make 13 decisions during any given mixed analysis process, which yielded an inclusive framework for conducting mixed analyses. These 13 sets of decisions are summarized in Table 3.

Table 3. Summary of Onwuegbuzie and Combs's (2010) 13-Criteria Meta-Framework for Mixed Analysis Techniques Used

Criteria

Rationale/purpose for conducting the mixed analysis

Philosophy underpinning the mixed analysis

Number of data types that will be analyzed

Number of data analysis types that will be used

Time sequence of the mixed analysis

Level of interaction between quantitative and qualitative analyses

Priority of analytical components

Number of analytical phases

Link to other design components

Phase of the research process when all analysis decisions are made

Type of generalization

Analysis orientation

Cross-over nature of analysis
How Criteria were Manifested in the Study

Involved complementarity and expansion (Greene, Caracelli, \& Graham, 1989)

Involved critical dialectical pluralist assumptions and stances (Onwuegbuzie \& Frels, 2013)

Collected both qualitative data and quantitative data (Creswell \& Plano Clark, 2010)

Utilized both qualitative analysis and quantitative analysis (Creswell \& Tashakkori, 2007; Onwuegbuzie, Slate, Leech, \& Collins, 2007, 2009; Onwuegbuzie \& Teddlie, 2003)

Involved sequential analysis (Tashakkori \& Teddlie, 1998; Teddlie \& Tashakkori, 2009)

Quantitatively analyzed the qualitative data (i.e., quantitized data) that informed the analysis of qualitative data at the previous stage (Teddlie \& Tashakkori, 2009)

Conducted qualitative-dominant crossover mixed analysis (Morse, 2003; Onwuegbuzie \& Combs, 2010)

Five analytical phases: data reduction, data display, data transformation, data correlation, and data integration (Onwuegbuzie \& Teddlie, 2003)

Not linked directly to any mixed research designs (Creswell \& Plano Clark, 2010; Teddlie \& Tashakkori, 2009)

Made mixed analysis decisions iteratively (Johnson, Onwuegbuzie, \& Turner, 2007)

Made analytic generalizations (Onwuegbuzie et al., 2009) Involved case-oriented analysis (Onwuegbuzie et al., 2009)

Quantitized qualitative data (e.g., effect sizes; Onwuegbuzie, 2003; Onwuegbuzie \& Teddlie, 2003); and correlated the quantitative and qualitative data (Onwuegbuzie \& Combs, 2010) 


\section{Results}

\section{Quantitative Findings}

Table 4 presents the $T$ scores pertaining to the NCQ scores for the eight NCQ scales. Because $T$ scores have a mean of 50 and a standard deviation of 10 , scores greater than 50 in Table 4 represent scores that are above the mean, whereas scores less than 50 represent scores below the mean. It can be seen that the 10 participants as a whole attained the highest $T$ scores for the Nontraditional Knowledge scale, with all participants attaining at least a $T$ score of 80 , which represents the 99th percentile. The Community Involvement scale provided the next highest $T$ scores, on average, with all but one of the participants scoring in the 88th percentile or higher. Interestingly, however, Matilda's Community Involvement only represented the 10th percentile. The next highest-scoring scale, on average, was Self-Concept, with $T$ scores ranging from the 19th percentile (i.e., Dixie) to the 87 th percentile (i.e., Beatrice and Calvin). Apart from Beatrice and Calvin, Sophia (i.e., 61st percentile) was the only other participant with a $T$ score above the mean. These three scales (Nontraditional Knowledge, Community Involvement, and Self-Concept) were the only three scales that yielded an average that was above the mean.

Table 4. Noncognitive Questionnaire Scores

\begin{tabular}{|c|c|c|c|c|c|c|c|c|c|}
\hline Alias & $\begin{array}{c}\text { Positive } \\
\text { self-concept } \\
\text { or confidence }\end{array}$ & $\begin{array}{c}\text { Realistic } \\
\text { self-appraisal }\end{array}$ & $\begin{array}{l}\text { Understands } \\
\text { and deals } \\
\text { with racism }\end{array}$ & $\begin{array}{c}\text { Prefers } \\
\text { long-range } \\
\text { goals to } \\
\text { short-term } \\
\text { goals and } \\
\text { immediate } \\
\text { goals }\end{array}$ & $\begin{array}{c}\text { Availabilit } \\
\text { y of a } \\
\text { strong } \\
\text { support } \\
\text { system }\end{array}$ & $\begin{array}{l}\text { Successful } \\
\text { leadership } \\
\text { experience }\end{array}$ & $\begin{array}{c}\text { Demonstrate } \\
\text { d community } \\
\text { service }\end{array}$ & $\begin{array}{l}\text { Knowledg } \\
\text { e acquired } \\
\text { in the field }\end{array}$ & $M(S D)$ \\
\hline Agnes & 45 & 60 & 14 & 55 & 5 & 41 & 72 & 81 & $46.63(26.47)$ \\
\hline Beatrice & 61 & 36 & 33 & 37 & 11 & 35 & 63 & 81 & $44.63(22.10)$ \\
\hline Calvin & 61 & 60 & 68 & 31 & 30 & 41 & 72 & 81 & $55.50(19.24)$ \\
\hline Constance & 49 & 30 & 38 & 31 & 42 & 47 & 72 & 81 & $48.75(18.56)$ \\
\hline Dixie & 41 & 37 & 27 & 41 & 42 & 42 & 62 & 80 & $46.50(16.62)$ \\
\hline Delores & 49 & 54 & 33 & 49 & 17 & 47 & 72 & 81 & $50.25(20.18)$ \\
\hline Hazel & 45 & 37 & 0 & 41 & 31 & 53 & 62 & 80 & $43.63(23.49)$ \\
\hline Matilda & 49 & 37 & 18 & 47 & 0 & 42 & 37 & 80 & $38.75(23.37)$ \\
\hline Sophia & 53 & 30 & 33 & 49 & 11 & 28 & 72 & 81 & $44.63(23.66)$ \\
\hline Thaddeus & 49 & 48 & 33 & 55 & 39 & 41 & 72 & 81 & $52.25(16.59)$ \\
\hline Mean & 50.2 & 42.9 & 29.7 & 43.6 & 22.8 & 41.7 & 65.6 & 80.7 & \\
\hline $\mathrm{SD}$ & 6.55 & 11.64 & 17.80 & 8.85 & 15.87 & 6.82 & 11.04 & 0.48 & \\
\hline
\end{tabular}

POSITIVE SELF-CONCEPT OR CONFIDENCE. Strong self-feeling, strength of character. Determination, independence.

REALISTIC SELF-APPRAISAL, especially academic. Recognizes and accepts any deficiencies and works hard at self-development. Recognizes need to broaden his/her individuality. 
UNDERSTAND AND DEALS WITH SYSTEM/RACISM. Realist based upon personal experience of racism. Is committed to fighting to improve existing system. Not submissive to existing wrongs, nor hostile to society, nor a "cop-out." Able to handle system. Asserts school or organization role to fight racism and change system.

PREFERS LONG-RANGE GOALS TO SHORT-TERM OR IMMEDIATE NEEDS. Able to respond to deferred gratification.

AVAILABILITY OF STRONG SUPPORT PERSON to whom to turn in crises.

SUCCESSFUL LEADERSHIP EXPERIENCE in any area pertinent to his/her background (gang leader, church, sports, noneducational groups, etc.).

DEMONSTRATED COMMUNITY SERVICE. Has involvement in his/her cultural community.

KNOWLEDGE ACQUIRED IN A FIELD. Unusual and/or culturally-related ways of obtaining information and demonstrating knowledge. Field itself may be non-traditional.

The Long Range Goals scale provided the next highest mean $T$ score. Here, only two participants (i.e., Agnes and Thaddeus) scored above the mean - with both being located at the 70th percentile. Calvin and Constance had the lowest $T$ scores, both being located at the 3rd percentile. The next highest scale, on average, was Realistic Self-Appraisal. Here, only Agnes, (84th percentile), Calvin (84th percentile), and Delores (66th percentile) had scores that were above the mean. Constance (2nd percentile) had the lowest $T$ score. The Realistic Self-Appraisal scale was followed by the Leadership scale, with only one participant, Hazel (i.e., 61st percentile), reporting having successful leadership experience that was above the mean. Sophia (1st percentile) reported having the least successful leadership experience. The second lowest scale, on average, was Understanding Racism, with only Calvin (i.e., 96th percentile) reporting understanding and dealing with racism that was above the mean. Finally, the Strong Support Person scale yielded the lowest $T$ scores, with no participant reporting scores pertaining to the availability of a strong support system that were above the mean, with Matilda reporting the lowest $T$ score and Constance and Dixie reporting the highest $T$ score (i.e., 21 st percentile).

Across the eight scales, on average, interestingly, the two men (i.e., Calvin and Thaddeus; $M$ $=53.88, S D=2.26)$ reported higher scores than did the women $(M=45.47, S D=$ 3.50) - yielding a Cohen's (1988) $d$ effect size of 2.49, which provided extremely strong evidence of a gender difference in NCQ $T$ scores. An ethnic difference in NCQ scores also was noted, with the three ethnic minorities $(M=42.96, S D=3.92)$ having three of the four lowest average scale scores and having a lower mean $T$ scores than did the White participants $(M=48.95, S D=4.05)$ - yielding an extremely large effect size of 1.49.

\section{Qualitative Findings}

Cross-case analysis. Before analyzing the interview data to extract emergent themes, we assessed the vagueness of words spoken by each participant (cf. Hiller, 1971). In order to accomplish this assessment, we used Hiller, Fisher, and Kaess's (1969) conceptualization of 
communication vagueness, which they defined as a "psychological construct which refers to the state of mind of a performer who does not sufficiently command the facts or the understanding required for maximally effective communication" (p. 670). WordStat 6.0 (Provalis Research, 2011b) was the software program that we used to assess the vagueness of each participant's story. WordStat 6.0 contains the following 10 categories of communication vagueness: ambiguous designation, negated intensifiers, approximation, bluffing and recovery, admission of error, indefinite amount, multiplicity, probability and possibility, reservations, and anaphora. Table 5 presents a description of each of these categories of communication vagueness. Figure 1 displays the frequency of vague phrases made by each participant across all 10 categories.

Table 5. Categories of Communication Vagueness
Category
Description

Ambiguous designation

Negated intensifiers

Approximation

Bluffing and recovery

Admission of error

Indefinite amount

Multiplicity

Probability and possibility

Reservations

Anaphora
Something potentially specifiable is mentioned but not specifically identified (e.g., thing, stuff, and so forth)

Negations can be evasions (e.g., not quite; not necessarily)

Reflects real or referential vagueness or imprecise knowledge or understanding (e.g., sort of, pretty much)

When a speaker/writer is not communicating effectively and attempts to shift responsibility for making sense of content to the listener/reader (e.g., actually, anyway)

Repeated admissions of error indicate a lack of confidence or competence (e.g., I made a mistake, I don't know)

An amount that is potentially knowable but is not specified (e.g., some, a couple, a few, a little, a lot)

Pseudospecification or glossing over of complexity (e.g., types, kinds)

Indicates lack of clarity or lack of definite knowledge (e.g., at times, generally)

Expressions of doubt or reluctance to commit to a particular point of view (i.e., appear, seems, maybe)

Excessive and repetitious use of pronouns instead of direct references that makes content more difficult to understand (e.g., she, he, it, them, their, latter, former) 


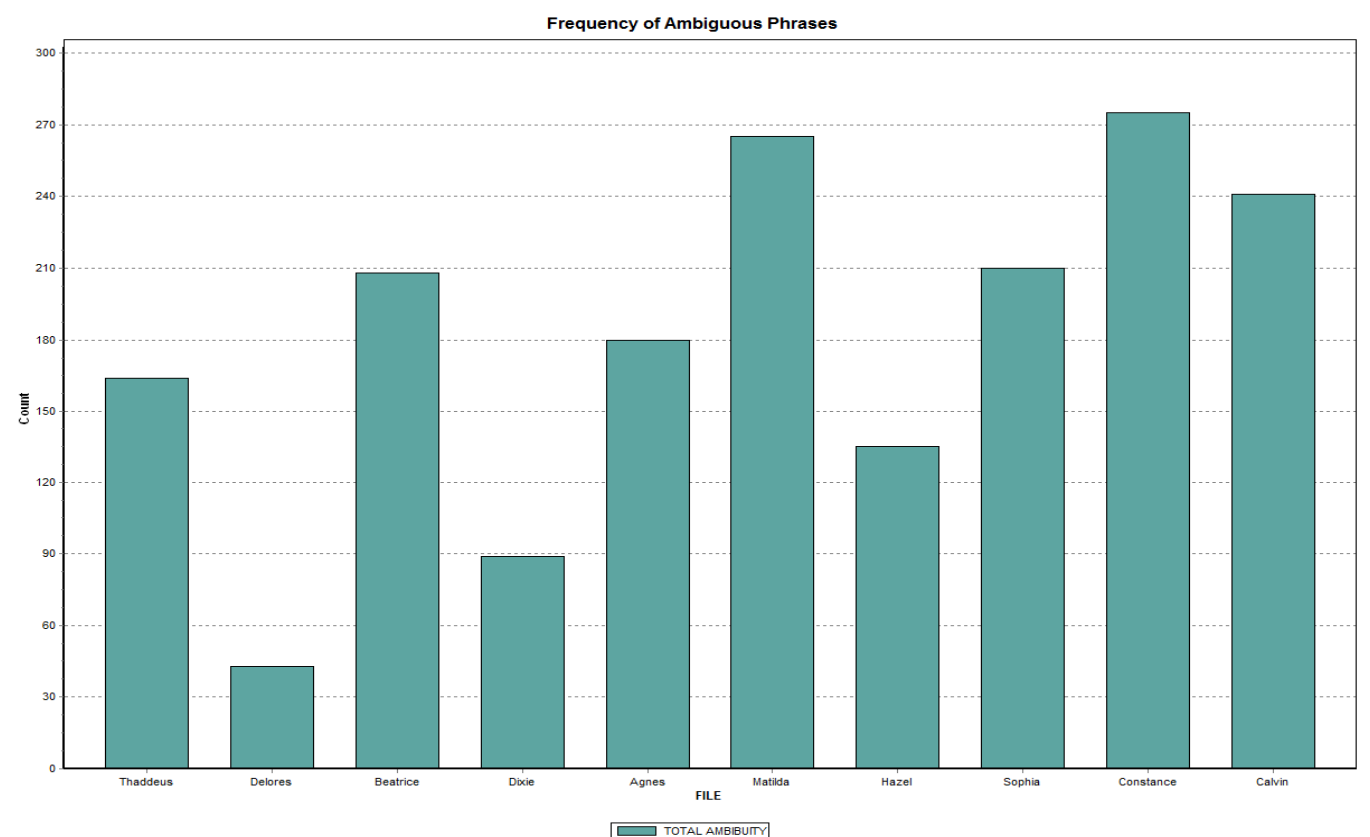

Figure 1. Frequency of ambiguous phrases stated by each of the selected participants

It can be seen from Figure 1 that Thaddeus, Delores, and Beatrice provided relatively high frequencies of vague phrases, whereas Calvin and Constance provided relatively low frequencies of vague phrases. Interestingly, although no pattern was apparent between the level of communication vagueness and the demographic variables of gender, number of children, and occupation, there appeared to be somewhat of a link between the level of communication vagueness and age, wherein, with one exception (i.e., Beatrice, who had the third highest level of communication vagueness), the participants in their $30 \mathrm{~s}$ had the lowest levels of communication vagueness, those in their 40s had the highest levels, whereas those in their 50s had moderate levels of communication vagueness. Also, there appeared to be somewhat of a link between the level of communication vagueness and ethnicity, with three minority participants having moderate levels of communication vagueness and the non-minority students — with one exception (i.e., Agnes) — having either low or high levels of communication vagueness. Thus, our analysis of communication vagueness allowed us to differentiate participants who were most clear about their experiences and perceptions regarding being a doctoral student from those who were less clear about these experiences and perceptions, which further facilitated our within-case analyses by providing additional nonverbal cues (cf. Denham \& Onwuegbuzie, 2013).

Figure 2 illustrates the 10 participants mapped, via correspondence analysis, onto the space that displays the 10 categories of communication vagueness. This figure shows how the participants related to each other with respect to these 10 categories. In the top left quadrant, it can be seen that Sophia, Beatrice, Delores, and Thaddeus clustered together nearest to the categories of indefinite amount, anaphora, and ambiguous designation, with Delores also clustering close to probability and possibility. In the bottom left quadrant, Hazel clustered 


\section{Macrothink

nearest to the categories of probability and possibility, multiplicity, negated identifiers, and approximation. In the top right quadrant, it can be seen that Calvin clustered together with Matilda, with Calvin being near to the categories of ambiguous designation and reservations and Matilda being near to the category of reservations. Finally, in the bottom fight quadrant, Constance, Agnes, and Dixie clustered together, with Constance occupying a position close to the origin and near to approximation, multiplicity, probability and possibility, anaphora, and ambiguous designation; Agnes being near approximation and bluff and recovery; and Dixie being near bluff and recovery.

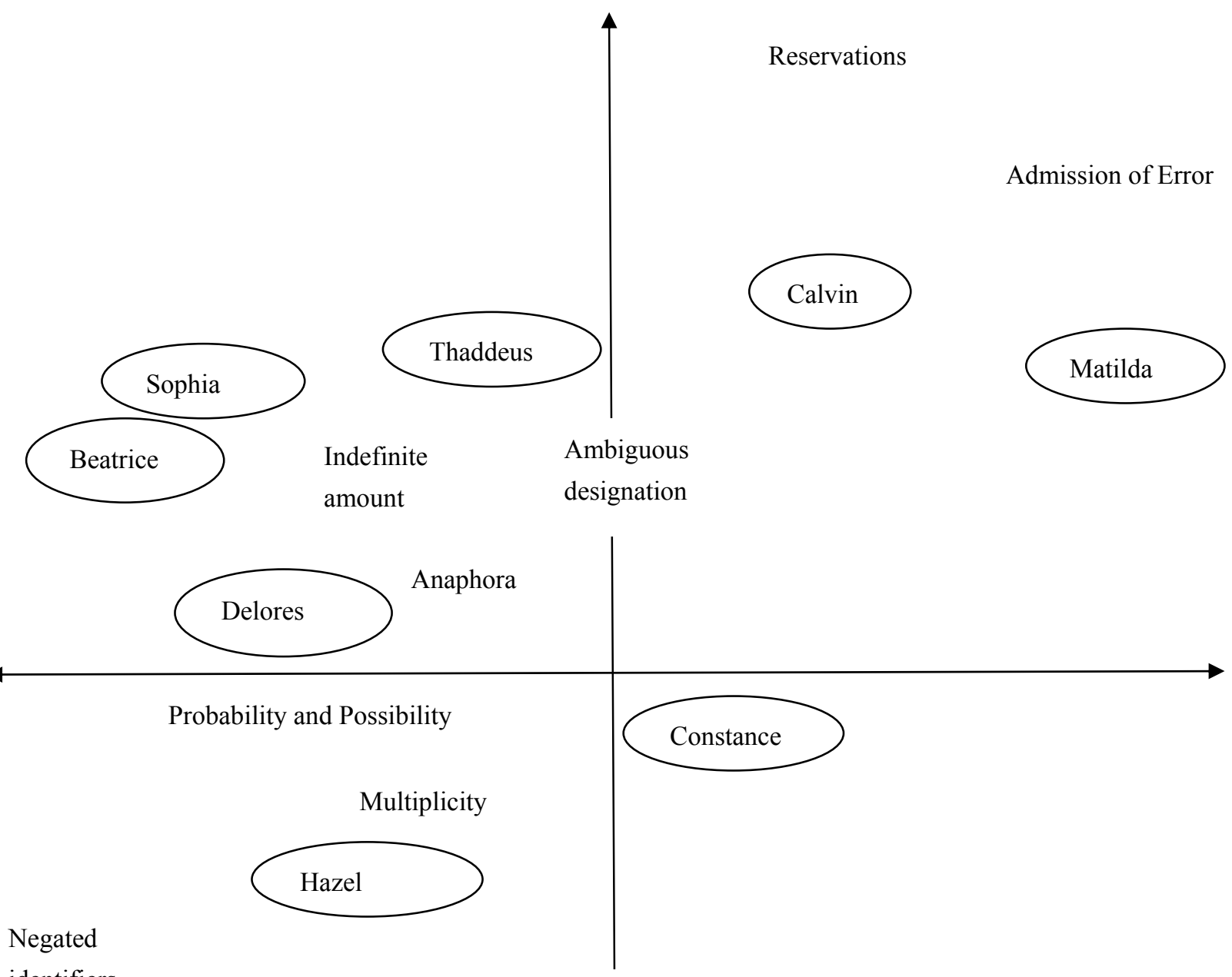

identifiers

Approximation
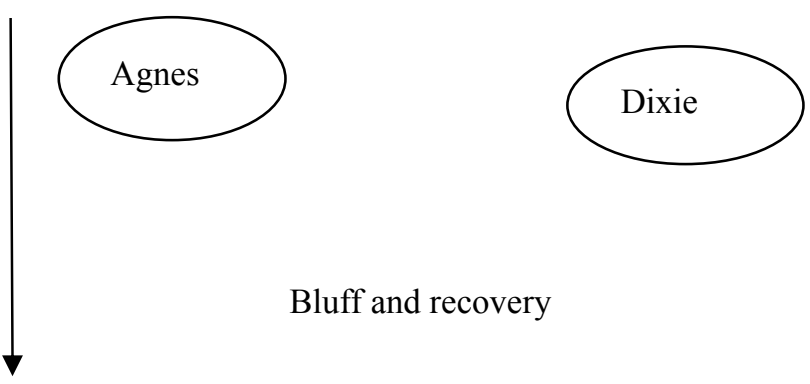

Bluff and recovery

Figure 2. Correspondence Analysis of the 10 Categories of Communication Vagueness 
Constant comparison analysis. A constant comparison analysis was performed on the data. To undertake this, we read through each interview transcript and responses to the follow-up questions in order to discern any significant motifs communicated by the participants. These motifs then were coded and examined for any common themes (Strauss \& Corbin, 1998). This analysis revealed 35 codes, which became the basis for four common themes that emerged from the data: identity, obstructions, coping, and remorse (see Table 6).

Table 6. Description of Themes Emerging from Constant Comparison Analysis

Theme

Identity

Obstructions

Coping

Remorse

\section{Description}

Included the interrelationship of references made to the different roles (e.g., student, spouse, parent) and subsequent responsibilities that each participant used to self-identify, references made to the interactions and relationships (e.g., family, friends) that were of importance to the participant, and references made to the expectations for both men and women as well to any noticed equalities and inequalities between genders.

Included references made to any specific difficulties or obstacles that the participants identified as challenging their abilities to succeed in their academic program.

Included references to any strategies or justification statements that aided the participants in continuing in their academic program.

Included references made regarding sacrifices that participants made in order to succeed in the program and subsequent feelings of guilt associated with these sacrifices.

Note. Codes were manually assigned to data using QDA Miner Version 4.0.3.

Classical content analysis. The classical content analysis followed the constant comparison analysis. Based on the coding frequency across cases, the participants as a group placed the most emphasis on identity codes (e.g., work identifier, student role, and personal identifier) and coping codes (references to a future job, coping strategies). However, in terms of single coding frequency, the most emphasis was put on the code mother role and responsibility, which occurred $8.3 \%$ of the time. Because only five of the respondents were mothers, and only three of these respondents were mothers of dependent children, the high occurrence of this code is an important observation and speaks to the singular experience of women doctoral students who are also mothers and primary caregivers to dependent children. The 35 codes were assigned to approximately 470 different chunks of data within the 10 transcribed interviews and the responses to the follow-up questions. Overall, the codes associated with the theme identity occurred most frequently, as compared to codes associated with other 
themes. Table 7 displays the frequency for the prominent code within each theme.

Table 7. Classical Content Analysis: Prominent Code within Each Theme and Their Frequencies

\begin{tabular}{|c|c|c|c|c|}
\hline Prominent Code & Category/Theme & $\begin{array}{l}\text { Frequency of } \\
\text { Code }\end{array}$ & $\begin{array}{c}\text { Frequency } \\
\text { of All } \\
\text { Codes } \\
\text { Within } \\
\text { Respective } \\
\text { Theme }\end{array}$ & $\begin{array}{l}\% \text { Code Used } \\
\text { Within Theme }\end{array}$ \\
\hline $\begin{array}{l}\text { Mother Role and } \\
\text { Responsibility }\end{array}$ & Identity & 39 & 288 & 13.54 \\
\hline Time & Obstructions & 21 & 63 & 33.33 \\
\hline Strategies & Coping & 23 & 80 & 28.75 \\
\hline Guilt & Remorse & 22 & 38 & 58.89 \\
\hline
\end{tabular}

Note. $\quad$ Obtained using QDA Miner Version 4.0.3.

Identity. The most dominant theme, identity, was demonstrated in the experiences of all participants. The theme was composed of the three subthemes of (a) roles and responsibilities, (b) relationships, and (c) gender expectations. Each of these subthemes was interrelated in terms of how each of our participants determined her/his own personal identity formation.

All participants mentioned the multiple roles that they experienced while participating in the doctoral program, including those of being an employee, a student, a parent, a grandparent, a spouse, a women, and/or an individual. Each of these roles had specific responsibilities that the participant judged as necessary, but often difficult to maintain. It became apparent that these roles were a focal point that dictated how the participants' time and energies were divided. It was a constant struggle to attempt to balance the multiple roles and subsequent obligations in a way that would allow success in each role. This attempted balance can be seen in Hazel's comment, "Most of time I try to combine my professional and personal lives. I travel with my daughter when I have to attend conferences."

Directly related to the subtheme of roles and responsibilities was the subtheme of relationships, which took into account all references to associations with others, including those interactions with family, with friends, with cohort members, with faculty members within the program, and with oneself. Relationships often were explained in a positive light, many times demonstrating support that the participant needed in order to persist in the doctoral program. When Beatrice discussed her relationship with her husband, she said, "We work very hard to communicate with one another, support each other, and try to find a balance as much as we can. If we didn't have that, I don't know how we could continue." 
However, relationships also could have negative impacts in some cases, with some mentions of strain and expectation. Matilda discussed being offended by comments directed towards her while at extended family gatherings:

I have been surprised however, with the preoccupation my family has had around my husband and I having children. It is a constant topic of conversation at family get-togethers, and it leads to comments such as 'I can't wait until you are done with school', or 'my goodness at this rate you will never have children'.

Several of these relationships tied into the subtheme of gender expectations. For example, one participant discussed how her relationship with her parents impacted her success in the program because her parents had specific cultural expectations for her as their daughter that did not align with her pursuit of higher education. This struggle is evidenced by the statement of Hazel, "My parents still have a notion of preferring a son to daughter. They have made great educational investment for their son, but unfortunately not for their daughter because they have different expectations for their son and daughter." It is important to note that these gender expectations often were intertwined with how participants defined themselves in terms of their roles and relationships, especially in cases in which the student was the primary caregiver for children. Beatrice defined herself as a student, employee, and primary caregiver, as shown by her comment:

Just arranging my life around school, at that time part time adjunct work, and my son who at 6 months was still nursing and still very dependent on me being at home with him and taking care of him, was very overwhelming.

Overall, in terms of gender expectations, the participants reported feelings of equality within the program. Several posited that this was because the field of education was dominated by women. The two men students both made comments about being in the minority. Thaddeus shared, "After a year and a half in the program I was the only man left in the classroom...I sometimes felt like I was representing 'the male point of view' in discussions." Additionally, Calvin referenced, "The males are largely outnumbered." However, even though the women did not cite inequality as a major factor in the program, there were some statements that did make mention of ways that the women did experience inequality due to gender, as shown by Delores's comment:

My impression of being a woman in a doctoral program was that I (as did other females) worked harder, took deadlines more seriously, approached group work more diligently and had more concern for the final product overall than did men in my cohort. Men, being a minority, appeared to enjoy a more 'privileged' status, and I do not believe that was by design.

Taken as a whole, this group of doctoral students - the women in particular - struggled with multiple factors in order to formulate their personal identities. They were never merely students or employees, but also had roles as caretakers, as spouses, and as family members that constantly begged their attention. Many times this caused the personal identity to fragment in such a way that several participants discussed having to compartmentalize 
aspects of their daily lives. As both a single mother of two young children and an employee who continued to work full-time throughout the doctoral program, Sophia explained:

I think my personal life differs tremendously from the personal life of a male during the doctoral program. I am unsure as to whether male students are required to play multiple roles (e.g., primary caregiver, primary financial provider for the household, and housekeeper) while attending a doctoral program. In short, the doctoral program taught me to compartmentalize my life.

This strategy had both negative and positive aspects associated with it and generated the theme of obstructions.

Obstructions. Due to these competing identities, the theme of obstructions permeated the interviews. Challenges of time management, workload, personal care needs, and caretaking of others were among the noted codes for this theme. Many students spoke to feeling overwhelmed in attempting to overcome these obstacles and often questioned why they persevered in the program. In terms of time management, Hazel discussed:

I struggle having to manage my time. Time management is a big issue with me. Because I have to take care of her [daughter], she's a really demanding 7 year old kid, a girl. She still needs me. While she's at school I'm working. So after work I have to spend a lot of time with her. Well study time is after I finish my duty as mom.

Similarly in terms of time management, Beatrice explained, "I really try to budget time. I really try to make a list and cross everything off, and focus my time on what's most important."

More specifically, we could see how deeply the students' competing identities caused difficulties in their pursuit of a doctorate degree. Constance discussed these difficulties:

Not only am I juggling school, a second job on the ranch, and my mother having cancer, I am also juggling my mother having cancer and working with her doctor's appointments and trying to get her better so that she can see me walk across the stage.

Agnes also referenced the importance of recognizing the relationship among her school life, professional life, and personal life, "It hits me at different times. I think it depends what's also going on you know in my professional life and in my personal life you know sometimes that all three of them don't jive quite right."

Coping. In order to justify and to mitigate the aforementioned obstructions, the participants utilized a variety of coping strategies. They discussed future employment opportunities, feelings of empowerment, individual motivation, optimistic justification, and personal care. These mechanisms helped the participants stay motivated and invested in the program. Specifically, nine of the 10 participants discussed the overarching goal of advancing their careers due to their continuation in the program. In order to cope with the day-to-day demands, Thaddeus looked at the overall picture, "In the end, the sacrifice that you put into it will seem small compared to the payoff that you will benefit from." He also stated, "You get that D R period in front of your name and, you know, I'll never have to go through that 
process again." Constance had a similar coping strategy with her comment, "It will all work out in the wash and be, ah, and all pay off in the end, and so I'm looking forward to it."

Being involved in the doctoral program also gave the students feeling of empowerment. Constance explained, "I do not feel intimidated by my male counterparts. If anything I feel a sense of accomplishment, pride, and perhaps a small amount of empowerment."

Personal care strategies to reduce stress were fairly individualized. Four examples included (a) working out (e.g., Sophia stated, "On weekends, I try to get in a long run."; Beatrice noted, "Following the birth of my son, I found a mommy's workout group."), (b) traveling (e.g., Delores commented, "I love to travel... I am still able to go visit my family and go travel, and make time, and not lose my track of my study."), and (c) taking personal relaxation days (e.g., Agnes stated, "I kind of regularly schedule special, um, times when we'll take off and go stay somewhere else for overnight or a weekend and we will make sure we include, you know, a massage.").

Remorse. However, the use of these coping strategies was not able to overcome the emphasis that participants placed on feelings of guilt and sacrifice. One half of the participants mentioned feelings of guilt that were associated with being involved with the program. The three mothers in the program who had young children living at home, in particular, gave vivid descriptions of how being in the program impacted their time with their children. While participating in a required internship for the program, Beatrice stated, "I missed my son's second birthday because I was in Costa Rica." As a single mother of one child, Hazel explained, "I cannot be involved with school activities of my daughter." Sophia, a single mother of two children, provided a description of the feeling of guilt that she encountered as a result of being enrolled in the program:

I feel like I have 'lost' the past two and a half years of mothering with my daughters. I meet their basic needs, but I seldom get to play and enjoy their company. Occasionally, the feelings of guilt are overwhelming, and these feelings can bring uncontrollable tears. As a mother, I made a very selfish decision to complete a doctoral program; I did not ask for my daughters' input. They have sacrificed so much to accommodate my desire to complete this doctoral program...I treasure the short segments of time that I spend with my daughters; the time is priceless. I cannot give them endless amounts of my undivided attention, but I can give them small amounts of 'me'.

It appeared that all the mothers in the program continued to take responsibility for the primary care of their children while they were enrolled in the program. In contrast, Thaddeus - the only man in the program who had a young child at home-stated, "I would often have to miss dance classes, piano recitals, play dates, or other child related functions because I was in class or I needed to get school work done." Although Thaddeus failed to attend child-related activities, he still owned the feeling of guilt for his involvement in the program, as shown by his statement, "This would sometimes lead to a degree of family strife, and feelings of guilt in me." 


\section{Macrothink}

International Journal of Education

ISSN 1948-5476

2015, Vol. 7, No. 1

The correspondence analysis shown in Figure 4 illustrates the mapping of the 10 participants onto the space that displays the four common themes that emerged during the constant comparison analysis. This figure shows how the participants related to each other with respect to these four emergent themes. In the top right quadrant, it can be seen that Beatrice and Sophia clustered together nearest to the theme of remorse, with Hazel and Thaddeus also clustering in close proximity of Beatrice and Sophia. All four of these participants had young children at home. In the bottom half plane, Calvin and Matilda clustered nearest to the theme of identity. Both Calvin and Matilda were married with no children. In the top left quadrant, Constance, Delores, and Agnes clustered together being near to the theme of coping. Finally, the correspondence plot reveals that Thaddeus resides near the origin (i.e., Thaddeus is the only participant that is equally spaced among all four themes).

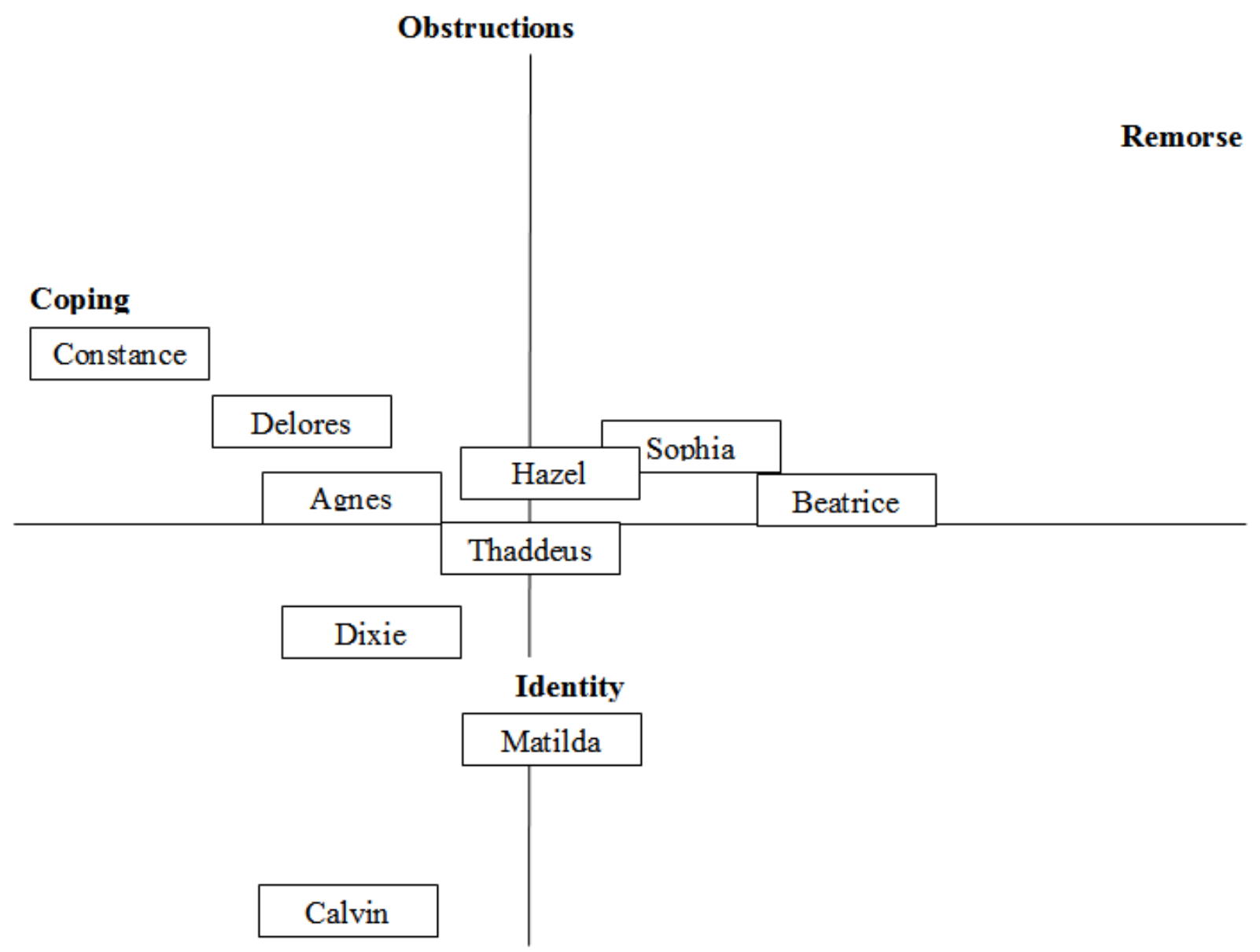

Figure 4. Correspondence Analysis of the Four Themes

Analysis of nonverbal communication data. Of Ekman's (1999) 15 fundamental emotions that are associated with innate facial expressions and that are all distinguishable from each other (i.e., amusement, anger, contempt, contentment, disgust, embarrassment, excitement, fear, guilt, pride in achievement, relief, sadness/distress, satisfaction, sensory pleasure, shame), the participants displayed between two (Calvin) and 11 (Agnes) fundamental emotions. Interestingly, the most dominant emotion exhibited was pride in achievement $(n=$ 10; which means that all participants expressed this emotion at some point during the 


\section{Macrothink

interviews), followed by satisfaction $(n=8)$ and excitement $(n=7)$. In fact, in general, positive emotions were displayed much more than were negative emotions by the participants. The most common negative emotion displayed was guilt $(n=5)$, followed by sadness $(n=4)$ and fear $(n=3)$. All other negative emotions were exhibited by two (embarrassment) or less (anger, contempt, shame yielded $n=1$; disgust was not exhibited by any participant) participants. Thus, despite the challenges faced by the study participants, consistent with the verbal responses, they were overall positive about their doctoral experiences.

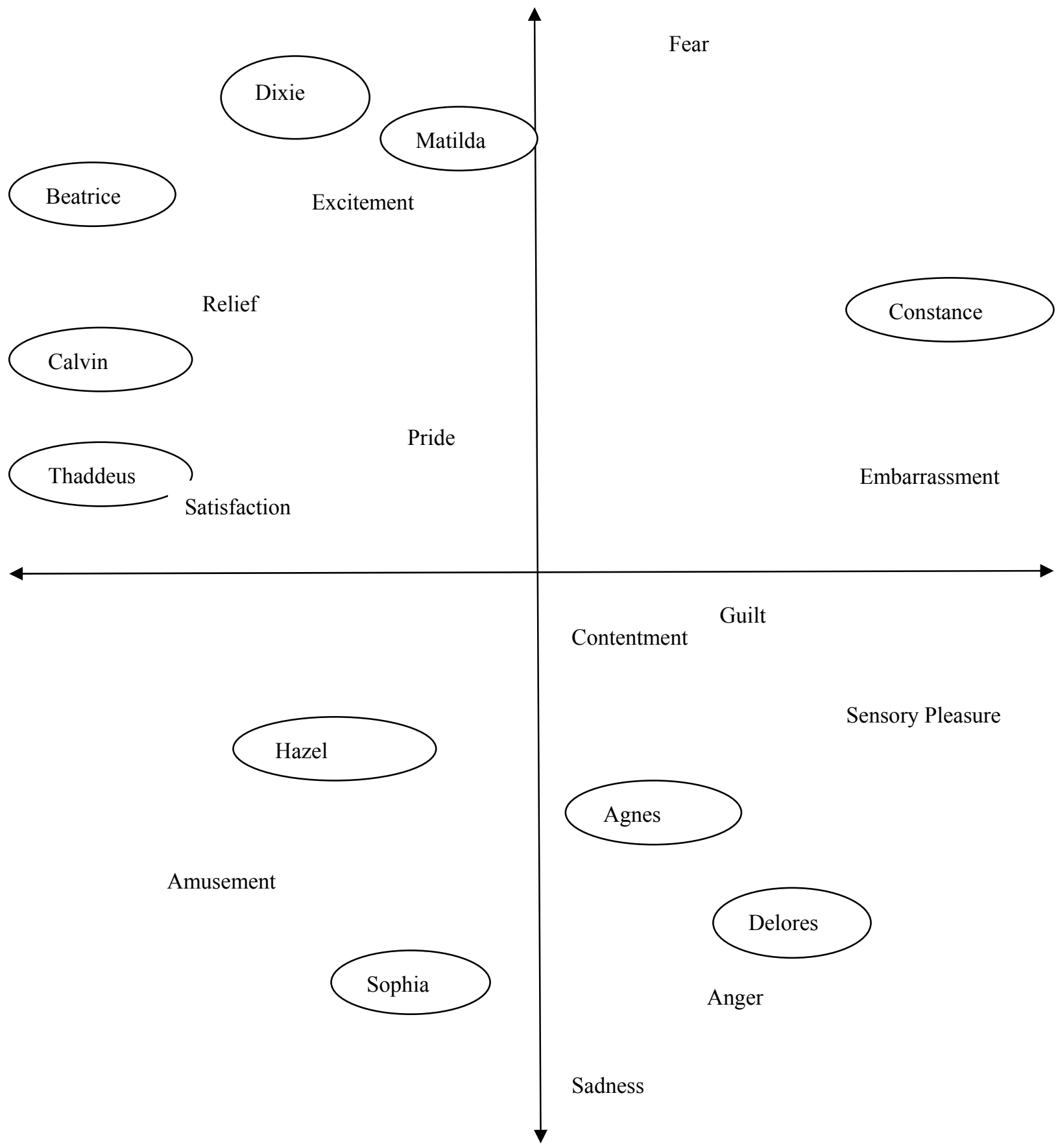

Figure 3. Correspondence Analysis of Ekman's (1999) 15 Emotions

Figure 3 illustrates the 10 participants mapped, via correspondence analysis, onto the space 
that displays the 12 emotions out of Ekman's (1999) 15 emotions that were observed across the interviews. Specifically, the correspondence plot primarily separates the positive emotions from the negative emotions, with the left hand quadrants containing five positive emotions and the right hand quadrants containing five negative emotions and only two positive emotions. More specifically, Beatrice, Calvin, Thaddeus, Dixie, and Matilda clustered around the positive emotions of excitement, relief, pride, and satisfactions (cf. top left quadrant); Hazel and Sophia clustered around the positive emotion of amusement (cf. bottom left quadrant); Constance, by herself, clustered around the negative emotions of fear and embarrassment (cf. top right quadrant); and Agnes and Delores clustered around the negative emotions of guilt, anger, and sadness and the positive emotions of contentment and sensory pleasure (cf. bottom right quadrant).

Within-case analysis. Because of the impact that the theme of remorse seemed to have on our participants, especially when centered on the idea of children, we undertook an in-depth, within-case analysis of one woman student without children (i.e., Matilda), one woman student with dependent children (i.e., Beatrice), and one man student with a dependent child (i.e., Thaddeus).

\section{Woman, without children.}

Matilda. Matilda was a 33-year-old married Black woman with no children. She worked in higher education for 10 years, and for the last 3 years served as an Academic Program Manager for a 4-year university.

Although Matilda did not have children when the study was conducted, she felt the pressure from immediate and extended family to have children. Her feeling of guilt emanated from her decision not to conform to her family's expectation of her serving in the role as a mother. As long as Matilda participated in the program and did not produce a child, she was forced to confront other feelings of the pursuit of her degree and the subsequent feelings of guilt that it caused:

My parents were always very gun-ho about my sister and I attending college. My mother in particular stressed the importance of women acquiring a college degree. So, I was quite surprised at my parents' response to my announcement of applying to a doctorate program. The focus of conversation shifted quickly from well wishes to "what about children? And, is this the best decision with [your husband] working to complete his program?" After this initial conversation I felt all kinds of emotion, but what surfaced most were feelings of guilt and as absurd as this may sound, shame.

As stated, Matilda was confused by the support that her family showed regarding their support for her husband staying in school and his career aspirations. This confusion likely explains, at least in part, the fact that, of the 10 participants, she yielded the second highest frequency of ambiguous phrases (i.e., communication vagueness) during her interview - particularly displaying admission of error, which indicate a lack of confidence or competence. Also, interestingly, Matilda reported the lowest overall NCQ score, with the lowest demonstrated community service. In particular, Matilda reported the lowest 
availability of a strong support system and one of the least positive self-concept or confidence and realistic self-appraisal. In addition, Matilda found the discussion around her educational pursuits difficult, as evidenced by the guilt and sadness that she displayed at times during her interview. She indicated that much of her discomfort comes from having to justify her career decisions, as well as the decision to delay having children:

It seems that along with the discussion around school and work is this intense focus on whether or not my husband and I plan to have children, and my as well as his family viewing my decision to advance my education as the culprit even though my husband is also pursuing credentials beyond that of his graduate degree.

When looking back on her upbringing, Matilda revealed that a strong emphasis was placed on education by her parents, and that acquiring a college degree was an expectation because her own parents had lacked the opportunity to attend college. When deciding to enter into a doctorate program, Matilda found that she received an abundance of support from her colleagues, supervisors, and former undergraduate and graduate instructors. In contrast, her parents, who had been very supportive of her pursuit of undergraduate and master's degrees, were apprehensive of her decision to pursue a doctorate degree because of what they considered to be a hardline focus on her professional ambitions - again supporting her zero $T$ score with regard to the NCQ scale representing the availability of a strong support system. This feeling was magnified by her extended family members who believed that she and her husband, who also had acquired a graduate degree, were at a particularly "good point" in their lives to have children:

There is a general consensus that due to our education and employment as Black people, that we should be focused on having children. There is this undertone, of our pursuits and personal expectations as being too farfetched or that enough effort has been placed on these areas, and that we should consider slowing down to have a family.

As Matilda expressed, some family members shared an expectation that because Matilda and her husband had graduate degrees and sound employment, the two of them were obligated to have children, and to offer a Black child an opportunity that all too often was considered to be "uncommon" for most Black children.

As Matilda continued to progress through her doctorate program, she found it increasingly difficult to attend family gatherings without her and her husband's "reproductive progress" or "obligation to have children" becoming a topic of conversation. Much of what Matilda gathered from the sentiments of family members was an expectation for women to downgrade their professional pursuits in order to avoid the perception of seeming "over ambitious" and consequently "outshining" their spouse:

I remember my husband having to have a conversation with family when I first entered the doctorate program regarding our decision to delay having children and explaining that my worth as a women, as a human being is not tied to whether or not I birth a child or become a mother. I was shocked, but his family was dumbfounded. 
They could not understand or relate to his way of thinking.

Matilda further shared that for women, not only is the expectation to be that of caregiver, but to be caregiver at the expense of one's own idea of what it means personally to be excellent. Furthermore, what most surprised Matilda was the perception by others that her actions were a challenge to that of her husband's own career goals and decisions. It was unsettling to Matilda that the perception of family members regarding her educational pursuits were that her husband was uncomfortable with his career choices, or that she and her husband did not come jointly to the decision that Matilda's pursuit of a doctorate degree was necessary, or that it was impossible that having children was not a central priority for them:

What really annoyed me more than the debate around why we had decided up to this point not to have children, was the innuendo that I was somehow challenging my husband by pursuing education beyond that which he had acquired, or that my pursuit of a doctorate degree wasn't necessary because I am not the "bread winner". This bothered me more than anything else.

Moreover, in reflecting on her experience, Matilda considered that some of the source of the sentiments shared by her family was possibly a result of the comparative nature of human beings. What Matilda believed to be a necessary path for her personally and professionally, others viewed as a reflection or comparison of their personal expectations or accomplishments. The result of this nature of comparison was a notion by family members that Matilda coined as the "better-than syndrome." Matilda shared that much of the feelings expressed by family members she believed were projections of feelings that her pursuit of a doctorate degree caused her relatives to feel that she considered herself to be elevated to that of others. Moreover, Matilda shared that the relationships and conversations with those in her cohort helped her to combat the expectations of others and the resulting feelings of guilt. Furthermore, while displaying contentment, satisfaction, and pride during this phase of the interview, Matilda cited that the likeness of experience and depth of understanding by those in her cohort helped to give her perspective, and to rejuvenate positive feelings about her choices to pursue a doctorate degree:

Honestly, if it were not for friends both in my particular doctorate program, in addition to a couple of close friends pursuing doctorates from another institution, I don't know if I would have made it to this point. There is an understanding that we have of one another's trials and tribulations that can only be understood due to our shared experiences.

Woman, with children.

Beatrice. Beatrice was a 30-year-old married White woman with one small child and who became pregnant with her second child during the course of this study. At the start of her doctoral program, Beatrice had a 6-month-old son and was working as an adjunct professor at a local community college system. As her time in the doctoral program progressed, Beatrice left her job at the community college system in order to focus primarily on her roles as a mother and as a student. 
As a self-described "recovering perfectionist," Beatrice struggled with maintaining high-quality academic work while also fulfilling her goal of being an available and supportive parent to her children - as reflected by the fact that she reported one of the least realistic self-appraisal via the NCQ instrument. Her feelings of guilt stem from the fact that she feels that she is not providing the quality of care that she desires for her children due to the demands of the program. She references that balancing these two roles are a constant challenge for her:

There are so many times that I feel I have to choose school versus family. Do I spend time with my son or do I pop in Sesame Street to get an hour to work on my paper? I know that this time with him as a little boy who wants to be with me is fleeting, and I constantly struggle with making sure I take advantage of the opportunity to be home with him and the opportunity to further my education. Having two nights away from a week him during one semester was horrible; I would hope to never have to do that again. I felt that I barely got to see him! I also have him in pre-school 2 days a week in order for me to have more time to work, and losing that time with him also makes me feel guilty.

Beatrice was the primary care giver of the first child, and she planned to assume the same role with the second child. Her plans likely explain why she reported a low score on the Long Range Goals scale, indicating that she preferred pursuing short-term goals and immediate goals rather than long-range goal. Both she and her husband were from out of state and had no family in the area to help them. This lack of a familial support system-consistent with her low score regarding the availability of a strong support system on the NCQ scale - adds to the difficulty that she faced while attempting to attend graduate school and raise a family, especially because Beatrice's husband was employed full-time and was the financial supporter of the family. This adds another component to Beatrice's guilt, as she not only had to make sacrifices on her own part, but also had to ask her husband to do so as well:

I also feel guilty for the extra strain this puts on my husband. We have no family in the area to help take care of our son, so when I need to go or do something for school, such as a conference or a seminar or to view a dissertation defense, my husband has to rearrange his schedule.

In order to cope with some of this guilt and strain, Beatrice responded by building a support network. She credited her husband with being her main support:

Thankfully, we, my husband and I, work very hard to communicate with one another, support each other, and try to find a balance as much as we can. If we didn't have that, I don't know how we could continue.

The cohort also had been a source of support for her, with one member in particular supporting her through her goal of breastfeeding her son:

Nursing is difficult because I had to be away from my son and find appropriate times and places to pump (such as when I had to pump in my car directly prior to my admission interview). I was able meet these challenges, but it can be difficult, 
especially when you are unsure about discussing it with your professor and cohort members. Thankfully, one of the other cohort members had nursed her daughters and was a great support system for me.

In describing the positive effect of her cohort, she displayed pride, satisfaction, excitement, and relief. However, even having support systems in place can lead to unexpected additional guilt. For example, Beatrice referenced that she did have a babysitter that came a few hours each week to allow her to work on school assignments and her husband to work around the home, but that this arrangement also caused them both to feel guilty about not "having family time" with their son.

Beatrice had the additional challenges of being pregnant while in her doctoral program. Pregnancy had obvious physical and scheduling implications that impeded Beatrice's desire for success in the program. Now, not only did she feel remorse for putting her son in school so that she could have time to work on her schooling, but also she felt additional guilt by having to reallocate that time to accommodate doctor appointments:

As for being pregnant, being excessively tired and fitting doctor's appointments into your schedule can make it difficult to get work completed. I know in the early stages of my pregnancy, I was falling asleep by 7:30 PM and having to sacrifice work time during my son's school days so that I could attend doctor appointments. I am making it work, but it is an extra challenge that male students do not experience.

However, we do see an interesting transition in Beatrice's mindset over the course of our data collection. At the beginning of the research study, we noted her dual guilt for not performing up to her level of expectation in the program due to having children as well as her guilt for not, in her mind, performing to her level of expectation as a parent. By the end of the research process, within the follow-up questionnaire, we have the sense that Beatrice had come to terms with her decision and was making new priorities in her life. She acknowledged that stress due to her situation was unavoidable, but ended on a determined and slightly optimistic tone:

And it's all about to become more stressful since I am pregnant with our second child. We knew it was going to be tough, but we also knew we wanted a second child. This was the time in terms of our age, health, and finances. Thankfully, I will be on the writing stage of my program so my time will only be taken up by writing and not by classwork and class time. If it takes me extra time to finish, then so be it. I will just make whatever adjustments I need to in order to finish my degree and be able to enjoy my family.

For Beatrice, being in the doctoral program always was going to cause her to experience guilt and sacrifice. Her desire to be her definition of a "good" mother was in conflict with her desire to be her definition of a "good" student. As she has matured through her time in the program, however, her focus seems to be less on balancing her two roles and more on accepting that there may never be a true balance. Instead, she now acknowledged that one of her roles will need to take a backseat to the other. Based on her statements of "adjustments," 
"extra time," and "enjoy my family," we can surmise that she is placing more priority in her role within her family at this point.

Man, with child.

Thaddeus. Thaddeus was a 42-year-old married White man with one young child. He was working full-time as an Associate Director of Recreational Sports while in the doctoral program. His wife was a stay-at-home parent who homeschooled their 6-year-old daughter.

This was Thaddeus' second attempt at completing this specific doctoral program. His previous cohort contained mostly K-12 administrators and, being employed in higher education, Thaddeus felt out of place. His lack of passion at that time coupled with travel and family issues led to him leaving the program:

I'm in in ah program I probably don't like as much. Because I was in the program with a bunch of K12 superintendent kind of wanna be folks. And so I said that's enough. Plus my wife was having some big knee surgery and so I decided, nah, we're not, we're not going to do that. So, a couple years go by and the idea that I'd kinda stopped taking the doctoral program has always kinda in the back of my mind.

Upon finding out that a new higher education-focused cohort was being formed within the program, Thaddeus decided to attempt the degree again:

I mean, that opens a lot of doors for me. It opens the possibility of either going into teaching, which I could love to do, directing a large academic outdoor program, which I would love to do, um, or going into administration of some capacity, whether that be as a dean or vice president or president, you never know.

With this focus on accomplishment, Thaddeus began anew in the doctoral program. However, it was not long before he found out that there was still sacrifice involved. He specifically named time management as his biggest challenge:

I think time, like any like any doc student, time is their biggest issue and it becomes compounded when you have, ah, a wife and, ah, I have a 6-year-old now, who are both, there're both demanding of time. And so when I come home, I spend time with my wife and I spend time with my daughter and we have dinner together and then after dinner it's play with my daughter until she goes to bed, so just to give my wife a break and to let me have some time with my daughter. And then after that its um its spend time with your wife because she hasn't seen you all day (Laughs).

The other area of his life that was impacted by this challenge of time management was adjusting his lifestyle and hobbies. Thaddeus put great emphasis on his need to be outdoors and active. It could be inferred that this activity was essential to his mental well-being and an important part of his self-identity:

I also have had challenges with just my lifestyle. I enjoy taking trips and spending long periods of time outside and I've basically had to forego all of that in this program just because you can't disappear into the mountains for a week and be responsible for 
a bunch of reading material that you have to do. I wish! Um, I mean kinda giving up that part of myself has been, ah, almost as big a sacrifice as giving up the time that I get to spend with my family. Just because I don't have that, that kind of outlet anymore. So, um, that's, that's been a big, big, big challenge for me is kinda just buckling down and, and spending my weekends instead of going out and taking a hike or going paddle boarding or canoeing or kayaking or any of the things that I really love to do.

In order to deal with these challenges, Thaddeus attempted to stay organized and to compartmentalize his life. He would block out time both on his work and home calendars in order to work and be with his wife and daughter:

I mean, it was, there's a lot going on but I really need to be protective of that time with my family, so I need to protect that time for the school stuff as well. So, I think that's probably the best strategy I've used so far.

Sometimes this would mean up giving his weekends to go into his office and work for the day. The fact that he was able to devote a full day to his doctoral work was consistent with the NCQ finding that he reported one of the highest scores regarding availability of a strong support system. He attempted to be as equitable with his time as he could, but it was still difficult and it still caused feelings of guilt:

When I would arrive home after work, I would devote as much time as I could to my daughter before she would go to bed. After that, it was time to discuss the events of the day with my wife concerning our daughter or anything else that needed to be talked about. After my wife would go to bed, then and only then would the reading or writing get tackled. I would often have to miss dance classes, piano recitals, play dates, or other child related functions because I was in class or I needed to get schoolwork done. This would sometimes lead to a degree of family strife, and feelings of guilt in me.

Thaddeus justified these feelings by citing how he hoped to inspire his daughter and to provide better for her by completing his degree:

I know that someday, um, I want my daughter, who I think is the earth moon and sky to me, I want her to look at her father and say, daddy did this. And that means that I want her to aspire to do something like this someday. Um, and she can do whatever she wants, but I want her to know that her daddy did this. And impractically did it for her so that she can have a better life because someday, I can do something that makes more money and it's more gratifying and maybe I can take her on more trips (Laughs). But the sacrifices I am putting in to do this program that are going to benefit her someday.

This idea of "providing," both materialistically and inspirationally, was unique to Thaddeus. Being this type of provider seemed to be his primary role as a parent, as he was more focused on providing his daughter with his time and with the byproducts of his participation in the program. This long-term thinking was consistent with his NCQ scores, wherein he reported 
the highest score on the Long Range Goals scale, indicating that he preferred pursuing long-range goals rather than short-term goals and immediate goals. Interestingly, he reported the second highest overall NCQ scores. In terms of nonverbal communication, he displayed the second most emotions $(n=11)$. On the positive side, he displayed: amusement, contentment, excitement, pride, relief, satisfaction, and sensory pleasure; whereas, on the negative side, he displayed: anger, embarrassment, guilt, and sadness.

Comparison summary. Among our within-case participants, we saw several significant contrasts based on gender. The first notable contrast was between the expectations placed on Matilda and those placed on Thaddeus. Matilda was placed under the expectation that she should not be pursuing a doctorate degree and instead should be planning to become a mother in the near future and, thus, a caretaker to her child. Thaddeus, however, had left the program once before, only to decide to return. He mentioned no obstacles that hindered him in deciding to return to the program. There was no indication of external expectations for him to be more available to his current child or to father more children to grow his family. In fact, in Matilda's case, it was viewed that by her stopping her educational pursuits, she would be in the right time of her life to benefit her children and to provide them access to education. In contrast, Thaddeus made mention of how continuing his educational pursuits would benefit his daughter in the long run.

This notable division as to how and when educational pursuits can influence children seems to be related directly to the parenting expectations of each individual. In the case of Beatrice, for instance, she took on the primary caregiver role for her children. She mentioned the responsibilities of nursing her child, bathing her child, teaching her child, potty training her child, and being overall responsible for her child's health and welfare in addition to any of his extracurricular activities. Furthermore, due to her pregnancy, she was also responsible for the well-being of her unborn baby, having to structure and to organize her day carefully in order to receive adequate nutrition, rest, and medical care essential for a healthy pregnancy. Beatrice's caretaking experiences and expectations were in line with those experienced by our other women participants who were mothers to young children (i.e., Hazel, Sophia). Thaddeus, however, lists no such responsibilities. His function with his child seemed to be less that of a caretaker and more that of a provider. His employment and education provided for her needs and his main at-home parenting task appeared to be focused on providing her time and interaction. Although Thaddeus' wife was the primary caretaker of the child, it is of note that Thaddeus made no mention to caretaking responsibilities outside of interaction and attending extracurricular activities.

To this end, it was interesting to note Thaddeus's definition of work versus that of the mothers' definition of work in the study. In his interview, he stated that his stay-at-home wife "home schools our daughter so she doesn't work." This statement was notable because all of the mothers of young children who were in our study classified their caretaking role of children with the same level, if not more so, of responsibility of their employment. The level of time and importance that they invested into their roles as mothers was expressed as a "job" or "work" and very significant to them. Perhaps, Thaddeus was implying that his wife does not work "outside of the home," but he also implied a power differential between those 
women who work and those who rear children (i.e., do not "work") even when those who are the primary caregivers for the children categorize these responsibilities as legitimate work.

As we contrasted these differing levels of expectations, child-rearing responsibilities, and classifications of work based on the responses of our participants, we revealed how guilt and sacrifice differed by gender. Matilda and Beatrice felt a level of guilt based on their choices, Matilda for delaying starting a family and Beatrice for worrying that she was not providing adequate care and attention to her children. Thaddeus made no mention of guilt comparable to these circumstances. Also, Beatrice stated that her greatest sacrifice of being in the program had been taking time away from her family. Thaddeus, however, mentions taking time away from his family and from his extracurricular pursuits (i.e., outdoor recreational activities). He, in fact, rated these two sacrifices as being equal in his mind. This is unique because all of the mothers of young children in our study were adamant that time away from their children was the primary sacrifice that they faced and put no other sacrifice, not even sacrificing their own personal health (e.g., sleep, grooming, exercise) at the same level of sacrifice as losing interaction time with their children.

\section{Discussion}

The use of FST informed this study because it placed the experiences of commonly marginalized groups at the center of research (Swigonski, 1993). Perhaps most significantly, FST emerged as an emic vehicle to reveal and to make transparent the personal stories that were meaningful to each woman participant within a doctoral program culture. This process informed new knowledge (Harding, 2004a) and provided evidence for valid doctoral program research practice using a qualitative-dominant crossover mixed analysis (Onwuegbuzie \& Combs, 2010) to identify challenges and to inform interventions for improved success in obtaining a doctoral degree. As put forward by the participant-researchers in this study, many expressed experiences illuminating the multiple roles and responsibilities (Onwuegbuzie, Rosli, Ingram, \& Frels, 2014) and the different expectations that they realized due to their gender. The rich and thick descriptions of the experiences of men and women doctoral students with young children suggested that the journey for women doctoral students tended to focus on pursuing short-term and immediate goals, whereas, conversely, the men doctoral students focused on long-range goals. The use of the qualitative-dominant method of explicitly making transparent the unique feminist standpoints assisted the women participant-researchers in defining their personal experiences using a robust research design. Additionally, the simultaneous use of the correspondence analyses, illustrated using the QDA Miner software (see Figures 2, 3, and 4), made visible the comparison of participants' communication vagueness, their emotions, and their proximity to the four emergent themes (i.e. identity, obstructions, coping, and remorse). These findings provided an expanded etic lens for participant-researchers and readers of this research (Onwuegbuzie \& Combs, 2010). Specifically, the use of correspondence analysis to analyze and to report data resulted in a deeper understanding of obstacles and coping strategies that successful doctoral students exhibit. As indicated in prior research (Ülkü -Steiner et al., 2000), the relationships developed 
between doctoral students and faculty members served as a basis of support and as a central coping strategy that helped women doctoral students to remain motivated and invested in their doctoral studies. The impact of conducting a study focused on revealing select women doctoral students' successful navigation of their doctoral degree programs situated within the lived experiences of the participant-researchers and using a robust research design methodology, as in this study, served further to strengthen trust, collaboration, and positive relationships between the participant-researchers doctoral students and faculty members.

As Tinto $(1975,1993)$ posited, student retention is highly impacted by a student's ability to integrate into the social and academic environment of an institution. Furthermore, by focusing institutional efforts on creating opportunities for student engagement in campus-related activities and increased access of students to institutional/departmental resources, the goal of integrating students into the social and academic environment of an institution can be realized (Hawley \& Harris, 2006). Participants of this study were asked about their engagement in campus/departmental activities and the type of supports that were made available to them while in pursuit of their doctorate degrees. Most notably, the participants commented on the scholarships and travel funds offered to doctoral students to assist with the paying of tuition and travel to conferences. One student in particular, Hazel, who is both an international student and a mother, pointed out that her doctoral fellowship was an "extremely important resource...that provides a tuition waiver and a stable income for living in the United States".

Additionally, all students who reported accessing departmental resources highlighted the support received by their dissertation committee chairs. One such participant, Matilda, shared that, "my chair has been instrumental in my success in the doctoral program. I often find myself contacting her whether I have an academic or professional concern." Moreover, study participants such as Agnes, commented on the influence of mentorship from department faculty, "I have had such a supportive experience in this program, receiving support and encouragement to write and publish from doctoral program faculty." With regard to more specific support, study participants mentioned resources such as workshops presented by departmental faculty and the Institution's Office of Graduate Studies, statistics tutoring, and assistance with accessing needed software and materials such as SPSS and QDA Miner.

Although these services were deemed helpful, more can be accomplished. As an increasing number of women enroll in doctoral programs, the experiences of this population and the strategies employed to persist must be acknowledged by administrators of doctoral programs, in order to create and to promote systems of support that specifically empower women doctoral students successfully to complete their programs. For example, services such as family/student gatherings, distance education, and childcare options likely will help women doctoral students - at least the women doctoral students in our study - manage the competing needs of school, family, and work (Byers et al., 2014). Additionally, faculty members and doctoral student discussion panels/groups, and doctoral student organizations centered on female experiences can offer a forum for doctoral students and faculty members to increase their person-to-person interactions. As posited by Tinto (1998), increased academic and social interaction with faculty increases the likelihood of student persistence. Similarly, such 
development of services and student support systems should help women doctoral students better to cope with the challenges that they face, confronting obstructions around personal and work obligations, and reducing feelings of remorse and guilt.

Although the findings from this study largely reinforce prior research conducted on women doctoral student persistence, more examination is needed as to the emic and etic (i.e., emtic; Onwuegbuzie, 2012) viewpoints of the impact of these experiences on women doctoral student persistence. By exploring women's standpoints, a deeper understanding of the challenges that women doctoral students face and the coping methods that they employ can emerge. Future researchers conducting research in this area also should attempt to gather the experiences of more fathers within doctoral programs, specifically those fathers who take on a primary caregiver role (e.g., single fathers, stay-at-home fathers) so as further to contrast any gender differences. The knowledge of these experiences can offer institutions useful insights that can be used to develop more effective support systems for their women doctoral students. This understanding of student needs and subsequent support program development, in turn, could increase the success rates of women in doctoral programs, and help to reduce the current high rates of attrition.

\section{References}

Ancis, J. R., \& Sedlacek, W. E. (1997). Predicting the academic achievement of female students using the SAT and noncognitive variables. College and University, 72(3), 1-8.

Anderson, E. (2011). Feminist epistemology and philosophy of science. In E. N. Zalta (Ed.), The Stanford encyclopedia of philosophy. Retrieved from http://plato.stanford.edu/archives/spr2011/entries/feminism-epistemology

Bazeley, P. (2009). Analysing qualitative data: more than 'identifying themes'. Malaysian Journal of Qualitative Research, 2, 6-22.

Berelson, B. (1952). Content analysis in communicative research. New York, NY: Free Press.

Byers, V. T., Smith, R. N., Hwang, E., Angrove, K. E., Chandler, J. I., Christian, K. M.,...\& Onwuegbuzie, A. J. (2014). Survival strategies: Doctoral students' perceptions of challenges and coping methods. International Journal of Doctoral Studies, 9, 109-136.

Cohen, J. (1988). Statistical power analysis for the behavioral sciences (2nd ed.). Hillsdale, NJ: Lawrence Erlbaum.

Collins, K. M. T., Onwuegbuzie, A. J., \& Sutton, I. L. (2006). A model incorporating the rationale and purpose for conducting mixed methods research in special education and beyond. Learning Disabilities: A Contemporary Journal, 4, 67-100.

Crain Bertsch, T. M. (2012). The standpoint of homeless single mothers on recurrent episodes of homelessness. Unpublished Dissertation, Adelphi University School of Social Work, Garden City, New York. 
Crasnow, S. (2009). Is standpoint theory a resource for feminist epistemology? An introduction. Hypatia, 24, 189-192. http://dx.doi.org/10.1111/j.1527-2001.2009.01066.x

Creswell, J. W., \& Plano Clark, V. L. (2010). Designing and conducting mixed methods research (2nd ed.). Thousand Oaks, CA: Sage.

Creswell, J. W., \& Tashakkori, A. (2007). Developing publishable mixed methods manuscripts. Journal of Mixed Methods Research, 1, 107-111. http://dx.doi.org/10.1177/1558689806298644

Denham, M. A., \& Onwuegbuzie, A. J. (2013). Beyond words: Using nonverbal communication data in research to enhance thick description and interpretation. International Journal of Qualitative Methods, 12, 670-696.

Ekman, P. (1999). Basic emotions. In T. Dalgleish \& M. Power (Eds.), Handbook of cognition and emotion (pp. 45-60). Sussex, England: John Wiley \& Sons.

Frels, R. K., \& Onwuegbuzie, A. J. (2013). Administering quantitative instruments with qualitative interviews: A mixed research approach. Journal of Counseling and Development, 91, 184-194. http://dx.doi.org/10.1002/j.1556-6676.2013.00085.x

Glaser, B. G. (1965). The constant comparative method of qualitative analysis. Social Problems, 12, 436-445. http://dx.doi.org/10.1525/sp.1965.12.4.03a00070

Glaser, B. G., \& Strauss, A. L. (1967). The discovery of grounded theory: Strategies for qualitative research. Chicago, IL: Aldine.

Gorden, R. L. (1980). Interviewing: Strategy, techniques, and tactics. Homewood, IL: Dorsey.

Greene, J. C., Caracelli, V. J., \& Graham, W. F. (1989). Toward a conceptual framework for mixed-method evaluation designs. Educational Evaluation and Policy Analysis, 11, 255-274. http://dx.doi.org/10.3102/01623737011003255

Greenwald, A. G., Pratkanis, A. R., Leippe, M. R., \& Baumgardner, M. H. (1986). Under what conditions does theory obstruct research progress? Psychological Review, 93, 216-229. http://dx.doi.org/10.1037//0033-295X.93.2.216

Guba, E. G., \& Lincoln, Y. S. (1989). Fourth generation evaluation. Newbury Park, CA: Sage.

Guest, G., Bunce, A., \& Johnson, L. (2006). How many interviews are enough? An experiment with data saturation and variability, Field Methods, 18, 59-82. http://dx.doi.org/10.1177/1525822X05279903

Haraway, D. (2004). Situated knowledges: The science question in feminism and the privilege of partial perspective. In S. Harding (Ed.), The feminist standpoint theory reader: Intellectual and political controversies (1st ed., pp. 81-101). New York, NY: Routledge. 
Harding, S. (1993). Rethinking standpoint epistemology: What is "strong objectivity?" In L. Alcoff \& E. Potter (Eds.). Feminist epistemologies (pp. 49-82). New York, NY: Routledge.

Harding, S. (2004a). A socially relevant philosophy of science? Resources from standpoint $\begin{array}{llll}\text { theory's } \quad \text { controversiality. } & \text { Hypatia, } & 19, & \text { 25-47. }\end{array}$ http://dx.doi.org/10.1111/j.1527-2001.2004.tb01267.x

Harding, S. (2004b). Introduction: Standpoint theory as a site of political, philosophic, and scientific debate. In S. Harding (Ed.), The feminist standpoint theory reader: Intellectual and political controversies (1st ed., pp. 1-15). New York, NY: Routledge.

Hartsock, N. C. (2004). The feminist standpoint: Developing the ground for a specifically feminist historical materialism. In S. Harding (Ed.), The feminist standpoint theory reader: Intellectual and political controversies. (1st ed., pp. 35-53). New York, NY: Routledge.

Hawley, T. H., \& Harris, T. A. (2006). Student characteristics related to persistence for first-year community college students. Journal of College Student Retention: Research, Theory \& Practice, 7(1-2), 117-142. http://dx.doi.org/10.2190/E99D-V4NT-71VF-83DC

Hiller, J. H. (1971). Verbal response indicators of conceptual vagueness. American Educational Research Journal, $\quad 8, \quad 151-161$. http://dx.doi.org/10.3102/00028312008001151

Hiller, J. H., Fisher, G. A., \& Kaess, W. A. (1969). A computer investigation of verbal characteristics of effective classroom lecturing. American Educational Research Journal, 6, 661-675. http://dx.doi.org/10.3102/00028312006004661

Janesick, V. J. (2004). Stretching exercises for qualitative researchers (3rd ed.). Thousand Oaks, CA: Sage.

Johnson, R. B., \& Christensen, L. (2010). Educational research: Quantitative, qualitative, and mixed approaches (4th ed.). Thousand Oaks, CA: Sage.

Johnson, R. B., Onwuegbuzie, A. J., \& Turner, L. A. (2007). Toward a definition of mixed methods research. Journal of Mixed Methods Research, 1, 112-133. http://dx.doi.org/10.1525/sp.1960.8.2.03a00030

Kvale, S. (1996). Interviews: An introduction to qualitative research interviewing. London, England: Sage.

Lather, P. (1992). Critical frames in educational research: Feminist and post structural perspectives. Special Issue: Qualitative Issues in Educational Research, 31, 87-99. http://dx.doi.org/10.1080/00405849209543529

Leech, N. L., \& Onwuegbuzie, A. J. (2008). Qualitative data analysis: A compendium of techniques and a framework for selection for school psychology research and beyond. School Psychology Quarterly, 23, 587-604. 
http://dx.doi.org/10.1037/1045-3830.23.4.587

Leech, N. L., \& Onwuegbuzie, A. J. (2009). A typology of mixed methods research designs. Quality \& Quantity: International Journal of Methodology, 43, 265-275. http://dx.doi.org/10.1007/s11135-007-9105-3

Lincoln, Y. S., \& Guba, E. G. (1985). Naturalistic inquiry. Beverly Hills, CA: Sage.

Manning, K. (1997). Authenticity in constructivist inquiry: Methodological considerations without prescription. Qualitative Inquiry, 3, 93-115. http://dx.doi.org/10.1177/107780049700300105

Mansfield, K. C., Welton, A., Lee, P., \& Young, M. D. (2010). The lived experiences of female educational leadership doctoral students. Journal of Educational Administration, 48, 727-740. http://dx.doi.org/10.1108/09578231011079584

Maxwell, J. A. (1992). Understanding and validity in qualitative research. Harvard Educational Review, 62, 279-299.

Michailidis, G. (2007). Correspondence analysis. In N. J. Salkind (Ed.), Encyclopedia of measurement and statistics (pp. 191-194). Thousand Oaks, CA: Sage.

Miles, M., \& Huberman, A. M. (1994). Qualitative data analysis: An expanded sourcebook (2nd ed.). Thousand Oaks, CA: Sage.

Morse, J. M. (2003). Principles of mixed methods and multimethod research design. In A. Tashakkori \& C. Teddlie (Eds.), Handbook of mixed methods in social and behavioral research (pp. 189-208). Thousand Oaks, CA: Sage.

Nielsen, J. M. (Ed.). (1990). Introduction. In J. M. Nielsen (Ed.), Feminist research methods: Exemplary readings in the social sciences (pp. 1-37). Boulder, CO: Westview Press.

Nolan, M. R., Hanson, E., Magnusson, L., \& Andersson, B. (2003). Gauging quality in constructivist research: The Aldre Vast Sjuharad model revisited. Quality in Ageing 4(2), 22-27. http://dx.doi.org/10.1108/14717794200300010

Olesen, V. (2005). Early millennial feminist qualitative research: Challenges and contours. In N. K. Denzin \& Y. S. Lincoln (Eds.), The Sage handbook of qualitative research (3rd ed., pp. 235-278). Thousand Oaks, CA: Sage.

Onwuegbuzie, A. J. (2003). Effect sizes in qualitative research: A prolegomenon. Quality \& Quantity: International Journal of Methodology, 37, 393-409. http://dx.doi.org/10.1023/A:1027379223537

Onwuegbuzie, A. J. (2012). Introduction: Putting the mixed back into quantitative and qualitative research in educational research and beyond: Moving towards the radical middle. International Journal of Multiple Research Approaches, 6, 192-219.

Onwuegbuzie, A. J., \& Collins, K. M .T. (2007). A typology of mixed methods sampling designs in social science research. The Qualitative Report, 12, 281-316. 
Onwuegbuzie, A. J., \& Combs, J. P. (2010). Emergent data analysis techniques in mixed methods research: A synthesis. In A. Tashakkori \& C. Teddlie (Eds.), Sage handbook of mixed methods in social and behavioral research (2nd ed., pp. 397-430). Thousand Oaks, CA: Sage.

Onwuegbuzie, A. J., \& Frels, R. K. (2013). Introduction: Towards a new research philosophy for addressing social justice issues: Critical dialectical pluralism 1.0. International Journal of Multiple Research Approaches, 7, 9-26.

Onwuegbuzie, A. J., \& Leech, N .L. (2007). Validity and qualitative research: An oxymoron? Quality \& Quantity: International Journal of Methodology, 41, 233-249. http://dx.doi.org/10.1007/s11135-005-1098-1

Onwuegbuzie, A. J., Leech, N. L., \& Collins, K. M. T. (2008). Interviewing the interpretive researcher: A method for addressing the crises of representation, legitimation, and praxis. International Journal of Qualitative Methods, 7, 1-17.

Onwuegbuzie, A. J., Rosli, R., Ingram, J. M., \& Frels, R. K. (2014). A critical dialectical pluralistic examination of the lived experience of women doctoral students. The Qualitative Report, 19(5), 1-35. Retrieved from http://www.nova.edu/ssss/QR/QR19/onwuegbuzie5.pdf

Onwuegbuzie, A. J., Slate, J. R., Leech, N. L., \& Collins, K. M. T. (2007). Conducting mixed analyses: A general typology. International Journal of Multiple Research Approaches, 1 , 4-17. http://dx.doi.org/10.5172/mra.455.1.1.4

Onwuegbuzie, A. J., Slate, J. R., Leech, N. L., \& Collins, K. M. T. (2009). Mixed data analysis: Advanced integration techniques. International Journal of Multiple Research Approaches, 3, 13-33. http://dx.doi.org/10.5172/mra.455.3.1.13

Onwuegbuzie, A. J., \& Teddlie, C. (2003). A framework for analyzing data in mixed methods research. In A. Tashakkori \& C. Teddlie (Eds.), Handbook of mixed methods in social and behavioral research (pp. 351-383). Thousand Oaks, CA: Sage.

Poggenpoel, M., \& Myburgh, S. (2003). The researcher as research instrument in educational research: A possible threat to trustworthiness? Education, 124, 418-421.

Provalis Research. (2010). WordStat (Version 6.1.4) [Computer software]. Montreal, Quebec, Canada: Author.

Provalis Research. (2011a). QDA Miner (Version 4.0.3) [Computer software]. Montreal, Quebec, Canada: Author.

Provalis Research. (2011b). WordStat 6.0. User's guide. Montreal, QC, Canada: Author.

Ramazanoglu, C., \& Holland, J. (2002). Feminist methodology: Challenges and choices. London, England: Sage.

Sedlacek, W. E. (2004a). Beyond the big test: Noncognitive assessment in higher education. San Francisco, CA: Jossey-Bass. 
Sedlacek, W. E. (2004b) Why we should use noncognitive variables with graduate and professional students. The Advisor: The Journal of the National Association of Advisors for the Health Professions, 24(2), 32-39.

Stake, R. E. (2005). Qualitative case studies. In N. K. Denzin \& Y. S. Lincoln (Eds.), The Sage handbook of qualitative research (3rd ed., pp. 443-466). Thousand Oaks, CA: Sage.

Strauss, A., \& Corbin, J. (1998). Basics of qualitative research: Techniques and procedures for developing grounded theory. Thousand Oaks. CA: Sage.

Swigonski, M. E. (1993). Feminist standpoint theory and the questions of social work research. AFFILIA, 8, 171-183. http://dx.doi.org/10.1177/088610999300800203

Swigonski, M. E. (1994). The logic of feminist standpoint theory for social work research. Social Work, 39, 387-393.

Tashakkori, A., \& Teddlie, C. (1998). Mixed methodology: Combining qualitative and quantitative approaches (Applied Social Research Methods Series, No. 46). Thousand Oaks, CA: Sage.

Teddlie, C., \& Tashakkori, A. (2009). Foundations of mixed methods research: Integrating quantitative and qualitative techniques in the social and behavioral sciences. Thousand Oaks, CA: Sage.

Tinto, V. (1975). Dropout from higher education: A theoretical synthesis of recent research. Review of Educational Research, 45, 89-125. http://dx.doi.org/10.3102/00346543045001089

Tinto, V. (1993). Leaving college: Rethinking the causes and cures of student attrition (2nd ed.). Chicago, IL: University of Chicago Press.

Tinto, V. (1998). Colleges as communities: Taking research on student persistence seriously. The Review of Higher Education, 21, 167-177.

Ülkü-Steiner, B., Kurtz-Costes, B., \& Kinlaw, C. R. (2000). Doctoral student experiences in gender-balanced and male-dominated graduate programs. Journal of Educational Psychology, 92, 296-307.

U.S. News and World Report. (2012). America's best colleges 2012. Retrieved from http://colleges.usnews.rankingsandreviews.com/best-colleges/sam-houston-state-3606

\section{Copyright Disclaimer}

Copyright for this article is retained by the author(s), with first publication rights granted to the journal.

This is an open-access article distributed under the terms and conditions of the Creative Commons Attribution license (http://creativecommons.org/licenses/by/3.0/). 